\title{
EMPLAZAMIENTO Y MUERTE DE FERNANDO IV ENTRE PROSAS HISTÓRICAS Y ROMANCERO. UNA APROXIMACIÓN*
}

Fuera auténtico o imaginario el emplazamiento, lo cierto es que la repentina muerte de Fernando IV en septiembre de 1312 quedó asociada para siempre a ese reto sobrenatural, el mismo que lanzaron los Templarios contra el rey francés Felipe el Hermoso y el papa Clemente V o el arzobispo de Tarragona contra Pedro IV el Ceremonioso, por citar ejemplos más o menos coetáneos. Si los dos caballeros ajusticiados sin culpa existieron realmente y pudieron desear una adecuada venganza, la recibieron con creces por la voz de la comunidad cuando soldó al nombre de Fernando el apodo de "el Emplazado" y entregó así a la historia y a la fantasía poética una vida y un reinado bajo ese único y humillante lema.

La fuente de fecha más antigua que relata el emplazamiento y la muerte de Fernando IV es actualmente el ms. E de la Crónica de Alfonso XI, muy probablemente el códice copiado en 1376 por

* Una síntesis de este trabajo fue leída en "The 1986 Conference of the Association of Hispanists of Great Britain and Ireland", en Edimburgo; véase $L C o, 1986$, núm. 15, 102-104, en donde aparece un resumen de la discusión. Mi "aproximación" se habría quedado mucho más lejos de su objetivo, e incluso no habría emprendido su marcha, si no hubiera podido apoyarse en la ayuda de amigos y colegas ejemplares por su generosidad y escrupulosidad, empezando por María Cruz García de Enterría con sus visitas a las bibliotecas de Madrid, El Escorial, Barcelona y Santander, controlando y transcribiendo o consiguiendo fotografías de los manuscritos cronísticos y de otros materiales. Las páginas sobre la Genealogia de los Carvajales son deudoras de doña María Brey, viuda de Rodríguez-Moñino, que con su acostumbrada disponibilidad me proporcionó fotocopias de algunas hojas del manuscrito y de documentos anejos, y de Víctor Infantes de Miguel, no resignado cazador del manuscrito toledano perdido, a quien debo fotocopias de materiales relativos al texto de Galíndez, amén de un control de manuscritos de La bienandanza de 
orden de Enrique II para la cámara regia, como declaran los preliminares ${ }^{1}$. La narración ocupa una parte del capítulo $3^{\circ}$ que, con el $\mathrm{I}^{\circ}$ y el $2^{\circ}$, fueron trasladados de la zona final de la Crónica de Fernando $I V$ al exordio de la de Alfonso XI: en unos manuscritos encontramos los tres capítulos, en otros solamente el $3^{\circ}$, que además de la muerte de Fernando relata los primeros momentos de la sucesión ${ }^{2}$. Como de la Crónica del padre no se conocen manuscritos fechables con relativa seguridad en el siglo xiv, doy el texto que nos interesa según el dicho ms. E de la Crónica del hijo:

Et el rey salio de Jahen et fuesse para martos. Et estando en martos mando matar dos cavalleros que andauan en su casa que venieron y a riepto que les fazian por muerte de vn cauallero que dezien que mataran quando el rey era en palençia saliendo de casa del rey vna noche. Al qual cauallero dezian Johan Alfonso de benauides. Et estos caualleros quando los el rey mando matar con tuerto dixieron que enplazauan $\mathrm{Al}$ rey que paresciesse con ellos ante dios a Juizio sobre esta muerte que el les mandaua dar con tuerto De aquel dia que ellos morian a treynta dias. Et ellos muertos otro dia fuese el rey para la hueste a Alcaudete [...] Et el rey estando enesta cerca de Alcaudete Tomol vna dolençia muy grande et afincol en tal manera que non pudo y estar Et venose para Jahen et con la dolençia non se quiso guardar et comia cada dia carne et beui vino [...] Et el rey comio esse dia de mañana e libro con el Infante don Pedro et con esos omes bonos que y eran por que otro dia de mañana se fuessen ende para aquel fecho. Et enesse dia Jueues siete dias de setienbre. viespera de Sancta maria echosse el rey a dormir vn poco despues de medio dia. Et fallaron le muerto enla cama en guisa que nenguno non lo uio morir. Et eneste Jueues se conplioron [sic] los treynta dias del enplazamiento delos caualleros que el rey mando matar en martos $[\ldots]^{3}$.

Lope García. Para el Compendio de Almela me ha socorrido su futuro editor, David Mackenzie. Del manuscrito P de la Gran Crónica me ha enviado noticias y un cuidadoso extracto Michel García. A todos, mi agradecimiento.

${ }^{1}$ Informan sobre él F. Cerdé y Rico, en el Prólogo a su ed. de la Crónica de D. Alfonso el Onceno, Madrid, 1787, y D. Catalán, La tradición manuscrita de la "Crónica de Alfonso XI', Gredos, Madrid, 1974, pp. 16 ss. y 185 ss.

2 Estudia la compleja situación textual D. CATALÁn, op. cit., passim; para el problema de los tres capítulos movedizos, cf. en particular las pp. 185 ss., 198 n., 213, 255 n. y 272. Suprime estos capítulos, aunque reimprima la ed. de Cerdá, la ed. de $B A E$, t. 66, cuidada por C. Rosell.

${ }^{3}$ Biblioteca de El Escorial, ms. Y-II-10, ff. 6r-6v. Sirve de base para la ed. cit. de Cerdá. A propósito de la Crónica fernandina, A. Benavides, Memo- 
Después del siglo xiv vienen a nuestro encuentro numerosos manuscritos de ambas Crónicas, la de Alfonso casi siempre encabezada por el final del reinado anterior. Para el segmento textual que nos atañe, poco más de la mitad de tales manuscritos no ofrece variaciones de relieve respecto a $\mathrm{E}^{4}$. De los otros nos viene un suplemento de información, ya sea en el cuerpo del texto, ya en notas marginales; su evaluación sacaría gran ventaja de un exa-

rias de don Fernando IV de Castilla, Madrid, 1860, t. 1, p. 246, da noticias de un ms. del s. XIV de la Biblioteca de Osuna que ya había señalado Amador de los Ríos, pero fechándolo entre los siglos XIV y XV (I. LóPEz DE MendozA, Obras, ed. J. A. de los Ríos, Madrid, 1852, pp. 605-606), y que describirá en detalle M. Schiff, La bibliothèque du Marquis de Santillane, Paris, 1905, pp. 393395: indica varias manos, correcciones y notas, copia una larga advertencia (cf. infra, ms. 10.195 de la BNM) y lo asigna al s. XV. Ignoro sobre qué bases adscribe Benavides este ms. a la Biblioteca Osuna, no mencionada ni por Amador ni por Schiff. Ésta, que pudo ser una equivocación, más adelante (p. 696) confunde al lector cuando se alude a un ms. Osuna del s. XIV que relata la muerte del rey sin ajusticiamiento de los dos caballeros y sin emplazamiento. Galmés de Fuentes buscó sin éxito ese manuscrito, verificando la presencia de la "fábula" de los demás; cf. R. MenÉndez Pidal, Romancero hispánico, Espasa-Calpe, Madrid, 1953, t. 1, p. 310 n. En SchifF, op. cit., pp. 400-401 son dos los mss. tipo "Crónica de cuatro reyes"' (Alfonso X, Sancho IV, Fernando IV y Alfonso XI) que pasaron de la Biblioteca Osuna a la BNM: uno con letra del siglo XV y otro con letra del XIV, correspondiente al que tiene sigla $\mathrm{H}$ en D. Catalán (que lo considera del siglo Xv); cf. op. cit., p. 389. Benavides no pudo referirse a éste porque contiene el emplazamiento; puede que su referencia, vaga, fuera a alguno de los mss. Osuna de la Crónica de 1344, quc en efecto desconoce el emplazamiento, o que se tratara del ya aludido ms. 10.195 de la BNM. J. Simón DíAz, Bibliografía de la literatura hispánica, t. 3, vol. 1, C.S.I.C., Madrid, 1963, pp. 244-246, apunta diecisiete mss. de estas crónicas, tres de ellos del siglo XIV. Pero los estudios de D. Catalán, op. cit., y la ed. crítica de la Gran crónica de Alfonso XI, Madrid, 1976, t. 1, pp. 19 ss., nos imponen cautelas: el núm. 2298 de Simón (H de Catalán) sería del xv, el núm. 2299 (S) del XIv, con dudas, y el núm. 2300 (K) contiene la Crónica de Alfonso XI de dos manos, la primera de finales del XIV (y de ella sería el capítulo 3 con la muerte de Fernando) y la segunda del XV.

${ }^{4}$ Son los mss. E' (siglas de Catalán; ms. 821 de la BNM, s. Xv), F (829 de la BNM, s. Xv), H (10.132 de la BNM, s. XIV o más bien XV), K (K-I-13, B. Escorial, s. XIV-Xv), J. (10.209 de la BNM, s. Xvn), Ñ) X-II-3, B. Escorial, s. XVI), Z (Z-III-8, B. Escorial, s. XV), Z' (Y-III-10, B. Escorial, s. XVI), Z"' (Y-II-12, B. Escorial, s. XVI), S (317 de la Biblioteca Menéndez Pelayo de Santander, s. XIV o Xv), Y (82-1-3 de la Biblioteca Colombina de Sevilla, s. Xv); además los núms. 2304 (13.200 de la BNM, s. Xv) y 2314 (Biblioteca de Catalunya de Barcelona, s. XVI) de J. Simón Díaz, op. cit. Del mismo repertorio el núm. 2307 (Y-I-5, Escorial, s. XV in.) tiene incompleta la Crónica fernandina y parece que también el núm. 2313 (Y-III-11, B. Escorial, s. XVI); trae sólo la de Alfonso X el núm. 2311 (Y-II-13, B. Escorial, s. XVI) y las de 
men exhaustivo de los manuscritos completos y de sus múltiples grafías y de una mejor delimitación de fechas, tareas sólo parcialmente acometidas. El ms. 10195 BNMadrid (varias manos, s.xv), una "Crónica de cuatro reyes", concluye bruscamente el relato sobre Fernando IV en la mitad del capítulo $2^{\circ}$ de la Crónica de Alfonso XI; pero en el f. 159v, al final del manuscrito, con letra distinta y en rojo, una larga nota empieza a enumerar los datos ausentes en los varios reinados y para el de Fernando advierte, f. 160r: "en la historia del Rey don Fernando falles el nast ${ }^{\circ}$ del rey don a e su criança [?] e de como este rey dō frūñádo tomo alcandete e [?] de como mādo despeñar en martos los dos escuderos por la muerte de $\mathrm{jj}^{\circ} \mathrm{a}^{\circ}$ de benauydes e de como murio el rey de dolecia en jahen e otras cossas" 5 . En estos pocosrenglones notamos "despeñar" en lugar del genérico "matar", la categoría de "escuderos" en vez de la de "caballeros" y la curiosa ausencia del emplazamiento, de manera que la muerte del rey parece atribuida sin más a la "dolencia". El ms. N-III-12 de la BEscorial (s.Xv; $\mathrm{N}$ con sigla de Catalán, que lo juzga el "mejor representante conocido de la Crónica de cuatro reyes") abunda en notas marginales. De las cuatro que le tocan a nuestro trozo, sólo la primera es de interés y nos da la identidad de los caballeros ajusticiados: "dezia se los caravajales" (f. 145v) ${ }^{6}$. También del ms. 84-7-34 de la BColombina de Sevilla nos interesan solamente los márgenes. Es "obra de un erudito" que actúa ya entrado el siglo $\mathrm{XvI}^{7}$ y que abundantemente glosa y enriquece - pero su ma-

Alfonso X y Sancho IV el núm. 2312 (Y-II-15, B. Escorial, s. XVI). La Crónica de Fernando IV puede leerse en A. Benavides, op. cit., t. 1 y en el t. 66 de la $B A E$. Merecería una investigación concienzuda como la dedicada por $\mathrm{D}$. Catalán a la Crónica de Alfonso $X I$.

${ }^{5}$ M. SchIFF, op. cit., pp. 394-395, copia entera la nota, con alguna imprecisión. La letra pudo ser de mano de Johan de Salzedo, que al final declara haber recibido en préstamo el ms. de parte del Marqués de Santillana y haber informado a Alfonso de Tordesillas "moço dela camara, año de MCCCCXLIII". A mi juicio, de la nota se infiere que en el ms. faltaban las hojas finales del reinado de Fernando, y no sólo algunos detalles. La grafía del primer nombre de Benavides no es clara y Schiff lee "Rodrigo".

${ }^{6}$ Las otras tres rezan: "emplazamiento del Rei para delante dios", “aq'st gano alcabdete" y "murio el rey al plazo $\overline{\mathrm{q}}$ le pusieron aquellos $\overline{\mathrm{q}}$ injustamente mato".

7 D. Catalán, op. cit., p. 396. Una de las notas alude a Álvar Núñez Cabeza de Vaca y a la Florida. Haría falta distinguir bien las manos. He podido consultar cómodamente los dos manúscritos de la Colombina en junio de 1987 gracias a la amistosa gestión de Pedro Piñero y a la amabilidad de los bibliote- 
no no es la sola - un texto cronístico ('Cuatro reyes') que él mismo parece haber copiado. En el margen derecho del folio donde acaba el último capítulo del reinado de Fernando IV se lee: "11amauāse estos caualleros pero alfonso de Carauajal, e alfonso de carauajal y erā hermanos. Los quales despuesde degollados fuerō sus cuerpos despeñados de la peña de martos abaxo. peralfonso de caruajal avia muerto en valladoli $[$ sic] en cāpo aplazado antel rey a Pedro burō de benavjdes ante la puerta $\overline{\mathrm{q}}$ oy dia se dize $\mathrm{dl}$ campo por esta causa'. Notemos la identificación exhaustiva de los dos caballeros, su degollación y despeñamiento, la muerte de Benavides - Pedro Burón- atribuida a uno de ellos en un reto que tuvo lugar en un punto de Valladolid que del suceso tomó el nombre. Es la más amplia de las notas encontradas y sobre sus detalles volveré más adelante, al hablar de otros documentos.

Los restantes mss. presentan la identificación de los caballeros dentro del texto, según modos de disposición que nos hacen distinguir tres grupos. El ms. M-II-2 de la BEscorial (s.Xv; f. 235r) escribe: "mando matar dos caualleros que eran de los caruajal que dezian al vno diego alfonso e al otro pero alfonso su hermano". El ms. 10.277 de la BNMadrid (s.Xv) nos da un texto idéntico menos en el nombre del segundo hermano, que es "Juan alfonso" (f. 196v); lo mismo ocurre en los escurialenses del s.Xv Z-III-7, f. 208r y Z-III-12, f. 346v.

En el ms. 1660 de la BNMadrid (de 1519; sigla O) los datos aparecen unos renglones más adelante respecto a su colocación en los mss. que acabo de citar: "estos Cavallos que dezian al vno $\mathrm{p}^{\circ}$ de Carvajal e al otro don $\mathrm{a}^{\circ} \mathrm{su} \mathrm{hr}^{\circ}$ quando el Rei los mando matar" (f. 5r); y poco después: "se cunplieron los treinta dias del enplazamj ${ }^{\circ}$ de los Caballeros Carvajales hrs ${ }^{\circ}$ quel rrey mando

carios. Fruto de ese holgado curiosear entre todas las hojas del ms. fue el hallazgo de una nueva estrofilla del cantar contra el arzobispo don Alfonso Carrillo que asediaba Simancas en julio de 1465, fiel a Enrique IV, cantar que se inventó y resonó en la ciudad -y vivió largamente después- al ser quemada la imagen del sitiador por el populacho. Del cantar se conocían hasta ahora sólo los vv. "Esta es Simancas, don Opas traidor,/ esta es Simancas que no Peñaflor”, cf. M. FRENK, Corpus de la antigua lírica popular hispánica (siglos xo al xvii), Castalia, Madrid, 1987, p. 434, n. 902; los refiere la Crónica de Enrique $I V$ de Enríquez del Castillo. Y es al margen del cap. 67 de la transcripción de esa Crónica en nuestro ms. donde uno de los anónimos y eruditos anotadores, volviendo a escribir recompuestas en verso las líneas que en el texto iban a renglón seguido, agrega lo que revela ser un estribillo: "Mirad q quemastes en medio del dia/ aquellas aceñas de santa maria/ dezidnos donopas si asi lo

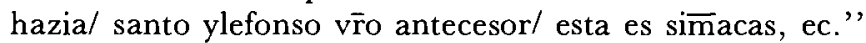


despeñar de la peña de martos" (f. $5 \mathrm{v}$ ). Contenido idéntico en el escurialense M-I-8 (s.xvi; $\left.\mathrm{O}^{1}\right)$, que además tiene en sus márgenes algunas frases de sumario (f. $6 r$ ). Una vez más cambian los nombres de los Carvajales, mientras vuelve a aparecer el despeñamiento.

En fin, el ms. 9-4761 de la Real Acad. de la Historia (fines s.xv;U) cita el apellido de los caballeros solamente al concluir el relato: "se cupplieron los treynta dias del Enplazamjento de los cavalleros Carvajales hermanos q el Rey mando despeñar de la peña de martos" (f. 117v). Idéntico reza $Q$, ms. de la BUniv. de Salamanca, del s.xvi.

La impresión que se saca de este control - que no me atrevo a considerar completo ${ }^{8}$ - de los mss. de las Crónicas de Fernando y de Alfonso es que detalles tan significativos como los nombres de los ajusticiados y la muerte por despeñamiento no pertenecían al dictado historiográfico más antiguo y que pueden haber penetrado en el texto en una fase tardía de su transmisión, absorbiendo tradiciones paralelas, posiblemente apuntadas en los márgenes de algunos códices, como sugiere la varia tipología que acabo de comentar, y que se da dentro de un segmento por lo demás bastante estable. Todo intento de confirmación o de rechazo de tal sospecha debe pasar por el examen de todos los mss. y la definición más circunscrita de sus fechas ${ }^{9}$.

Antes de concluir con la historiografía regia, veamos una tercera recopilación, la llamada Gran Crónica de Alfonso XI. Preparada en los últimos años del reinado de Alfonso o poco después de

${ }^{8}$ Doy dos ejemplos de manuscritos que conozco y no he podido alcanzar: el núm. B1498 de la biblioteca de la Hispanic Society de Nueva York, descrito por C. B. Faulhaber, Medieval manuscripts in the Libraxy of The Hispanic Society of America, The Hispanic Society of America, New York, 1983, n. 494, quien sugiere como época el s. XV in., con duda, aunque más abajo se apuntan los años 1460-1482 para la filigrana. Se trata de una Crónica de Fernando IV. El otro es el parisino de la Bibliothèque Nationale, Esp. 327; A. MoREL-Fatio, Catalogue des manuscrits espagnols et portugais de la Bibliothèque Nationale, Paris, 1892, pp. 49-50, que indica: "Année 1458".

${ }^{9}$ Acabamos de ver en la nota anterior y en las 3 y 4 lo genérico y a veces contradictorio que es el panorama de la cronología de los manuscritos. Un exceso de simplificación en las fichas descriptivas puede ser responsable de una nota genérica: la ficha relativa al escurialense Z-III-8 informa:" "Letra gótica del s. Xv, a plana entera", en J. Zarco Cuevas, Catálogo de los manuscritos castellanos de la Real Biblioteca de El Escorial, Madrid, 1929, t. 3, p. 137; pero a lo largo de una disquisición en el t. 2, Madrid, 1926, p. 466, el padre Zarco habla con toda seguridad de ese manuscrito como "de fines del s. $\mathrm{xv}$ ". 
1393, tuvo entre sus fines el de completar o ampliar los datos relativos a la onomástica de personas y lugares, aspecto que nos toca de cerca. El emplazamiento y la muerte de Fernando se relatan - como de costumbre- en el capítulo 3. Pero esa presencia de los tres capítulos, finales en la Crónica fernandina e iniciales en la de Alfonso, se da solamente en uno de los dos mss. conservados de la Gran Crónica, el ms. A (1015 de la BNMadrid), fechable entre los siglos XVI y xvII; el otro ms., P (Esp.329 de la BNParís), ss.Xv-XVI, considerado más próximo al original, no los contiene; como tampoco los contenía el ms., hoy perdido, que utilizó Barrantes para sus Tlustraciones de la casa de Niebla de 1541. Es probable que A los derivara de una tradición como la representada por el ms. perdido * $\mathrm{M}^{1}$, que a su vez reflejaba una Crónica de $A l$ fonso $X I$ desgajada de una "de cuatro reyes" 10 . Pero se da el caso de que el único testigo conocido más vinculado a esa tradición ${ }^{*} \mathrm{M}^{1}$, o sea el ms. M (323 de la BMenéndez Pelayo de Santander; s.XvI), no contiene los susodichos capítulos. Sí los tienen dos lejanos vástagos de esa tradición, los arriba citados mss. $\mathrm{O}$ y $\mathrm{O}^{1}$ que integran uno de los grupos ilustrativos de la tipología de injertos de los datos de identificación de los caballeros ajusticiados. Bajo este aspecto $\mathrm{A}$ coincide plenamente con $\mathrm{O}_{\text {y }} \mathrm{O}^{1}$, y los datos en cuestión ("que dezian al uno Pedro de Carabajal e al otro don Alonso su hermano", "Carabajales", "despeñar de la peña": cf. supra, ms. O) no deben entrar, como otros señalados por su editor, entre los privativos de la Gran Crónica de Alfonso XI frente a la "pequeña" 11 , ni lo son de A: son fórmulas viajeras, aunque dentro de tradiciones más bien definidas.

Pero en las últimas hojas del ms. P, después de unos capítulos sueltos agregados por la que parece la misma mano de la primera parte del ms. y a ella por lo tanto debido, se encuentra "un capítulo dedicado a Fernando IV con énfasis en el último año de su reinado"12. Está en el f. CCCCXXIII y su título reza: "Capitulo del rrey don fernando quarto fijo del rrey don sancho padre el rrey don alonso el onzeno que murio enplazado por los caruajales". El detalle final tiene el aspecto de la formulilla tardía; y en efecto, el contenido del capítulo desconoce cualquier identificación de los dos que llama "escuderos" como ignora el "despe-

${ }^{10}$ Para todo esto cf. Gran crónica de Alfonso XI, t. 1, pp. 20, 32-49, 230253 y 272.

11 Ibid., t. 2, apéndice 1; para el texto de A, cf. también t. 1, pp. 47-48.

${ }^{12}$ Ibid., t. 1, p. 253. No se da en el apéndice. 
ñamiento", presentando un perfil de nuestro segmento de tipo, diría, arcaico. ¿Una discordancia entre título y contenido del capítulo? No es fenómeno raro. Un examen cuidadoso de las grafías sería, una vez más, deseable. Un dato final: en una época el ms. $\mathrm{P}$ anduvo entre manos de un "Alonso de Carbajal señor de Tobarriela", como dice una notita en el recto de la primera de las hojas de guarda ${ }^{13}$.

Es muy probable que poco después de la mitad del siglo XV Diego Rodríguez de Almela diera conclusión a su Valerio de las Estorias escolásticas e de España, una de las recopilaciones históricodidascálicas más afortunadas durante siglo y medio ${ }^{14}$. En su Libro VI el Título III trata "De rigurossa justicia" y en el Capítulo $\mathrm{V}$ ofrece como ilustración del lema nuestro episodio:

Estando el Rey Don Fernando IV.de Castilla, que tomó á Gibraltar, en Martos, acussaron ante él á dos escuderos llamados el uno Pedro Carabajal, y al otro Juan Alfonso de Carabajal, su hermano, que ambos andaban en su Corte, oponiendoles que una noche estando el Rey en Palencia, mataron á un Caballero llamado Gomez de Benavides, que queria mucho el Rey, dando muchos indicios y presunciones, porque parescia que ellos le avian muerto. El Rey Don Fernando ussando de rigurossa justicia fizo prender á ambos hermanos, y despeñar de la peña de Martos; antes que los despeñassen dixeron que Dios era testigo, y sabia la verdad que no eran culpan-

${ }^{13}$ Id.

${ }^{14}$ R. B. TATE, Ensayos sobre la historiografía peninsular del siglo xv, Gredos, Madrid, 1970, p. 115, la supone acabada antes de 1456, año de la muerte del obispo de Burgos Alfonso García de Santa María, maestro y protector de Almela e inspirador de idea, estructura y partes de Valerio. La carta-dedicatoria de Juan Manrique lleva la fecha de 1472 sólo desde la ed. de Toledo de 1520, mientras en las dos más antiguas (Murcia 1487 y Medina del Campo 1511) tiene la de 1462. J. Simón Díaz, op. cit., t. 3, núms. 6162-6163 y 6171-6183, reseña dos manuscritos del s. XVI y doce eds. hasta 1587, más una del s. XVIII. Almela escribió también un Compendio historial (a punto de terminar en 1484), donde relata nuestro episodio sin grandes diferencias respecto a las Crónicas, cuya fraseología refleja a trechos; se nota la iteración de "matar e despeñar". El Compendio lo he consultado en un extracto del ms. 1979 de la BNM, f. CCLXXVIII, que debo a la amabilidad de D. Mackenzie, editor de las Cartas de Almela, Exeter, 1980; en la p. 81 se imprime por vez primera una carta de 1484 dirigida a Diego de Carvajal, corregidor de Murcia, donde se da noticia de la próxima conclusión del Compendio. Esta recopilación fue en parte reelaborada e interpolada por manos anónimas en el s. XVI, pero nada nuevo se ofrece en el párrafo que nos interesa, controlado en el ms. 1525 de la BNM. 
tes en aquella muerte que les oponian, y que pues el Rey los mandaba despeñar y matar á sin razon, que lo emplazaban de aquel dia que ellos morian en treinta dias que paresciesse con ellos á juicio ante Dios. Los escuderos fueron despeñados y muertos, y el Rey Don Fernando vino á Jaen. Acaesció que dos dias antes que se compliesse el plazo se sintió un poco enojado, comió carne, y bebió vino. Como el dia del plazo de los treinta dias que los escuderos que mató le emplazaron se compliesse, queriendo partir para Alcaudete, que su hermano el Infante Don Pedro avia á los Moros tomado, comió temprano, y acostósse á dormir en la siesta, que era en verano; acaesció assi, que quando fueron para le despertar, hallaronlo muerto en la cama, que ninguno no lo vido morir. Mucho se deben atentar los Jueces antes que procedan á executar justicia, mayormente de sangre, hasta saber verdaderamente el fecho porque la justicia se deba executar. Ca como en el Genessis se lee: Quien sacare sangre sin peccado, Dios lo demandará. Este Rey no tuvo la manera que convenia á execucion de justicia, y por tanto acabó como dicho $\mathrm{es}^{15}$.

El relato del emplazamiento ya llegaba a Almela de la tradición cronística con una potencial ejemplaridad que encuentra desarrollo y énfasis perfectos dentro del marco moralizante del Valerio. Respecto a la narración policéntrica de la historiografía, el capitulillo de Almela puede ahorrarse cualquier función informativa general y por lo tanto se concentra en el núcleo emblemático del suceso ${ }^{16}$ : se simplifica, por ejemplo, el vaivén del rey entre $\mathrm{Al}$ caudete y Jaén, y hay un solo asomo incidental y conciso (toma de Alcaudete por don Pedro) de materia extraña. Si el didascalismo por un lado reduce, por otro amplifica: nótese, por ejemplo, el inciso sobre la benevolencia del rey para con Benavides, implícita censura de parcialidad, y la refencia a "indicios" y "presunciones" que solos decidieron de la conducta de Fernando. La maniobra para enriquecer y extremar los ejes semánticos del relato

15 D. Rodríguez de Almela, Valerio de las historias de la sagrada escritura y de los hechos de España, ed. J. A. Moreno, Madrid, 1793, pp. 230-231. El editor sigue la impresión de Sevilla, 1542, séptima de la lista citada por Simón Díaz. Son mínimas las variantes respecto a las ediciones de Murcia 1487, Medina 1511 y Toledo 1520.

${ }_{16}$ Pero en una obra histórica como el Compendio ya el título del capítulo, el 577, delata el espacio y el color que el episodio tiene en la perspectiva de Almela: "commo el Rey don fernando enbio al ynfante don pedro su hermano con su hueste sobre la villa de alcaudete e la cerco e tomo. E los caualleros que mato en martos lo enplazaron ante dios. E murio el dicho Rey don fernando en Jaen conplidos los treynta dias del plazo". 
es suavemente decidida, y confiada a detalles: un inciso como " $u$ ssando de rigurossa justicia", una ligera alusión a la enfermedad como "se sintió un poco enojado" en contraste con la "dolencia muy grande" de las Crónicas ${ }^{17}$, el consiguiente "olvido" de subrayar lo perjudicial del comer y beber ${ }^{18}$, mientras sí había sido llamada la atención sobre el presentarse del malestar "dos dias antes que se compliesse el plazo". Con sutil estrategia, Almela ha construido un relato desprovisto de cualquier ambigüedad y entrega a sus lectores una fábula cuyos elementos y cuya moral no conocen matices; les entrega también la que muy probablemente es la primera interpretación del episodio y de los hermanos Carvajal como emblemas.

Por su época de redacción, el Valerio podría representar asimismo uno de los testimonios más antiguos de la identidad de los dos caballeros, dentro de la documentación manejada y con la ya aludida genericidad cronológica de algunos manuscritos cronísticos. Antes o al lado de estos mss. y de otras fuentes que de momento ignoro, el Valerio sin duda contribuyó, con su difusión todavía manuscrito y con su enorme éxito una vez impreso, a divulgar y afianzar una identificación que por aquellos años no creo estuviera ya tan arraigada. Y esto Rodríguez de Almela quizás pudo no habérselo propuesto, pero al constatarlo debió apreciarlo como una satisfacción más que le venía de su libro. Lo apreciaron sin duda los numerosos Carvajales esparcidos por la Península, que además podían agradecer al Valerio algunas otras páginas lindantes con las comentadas. En efecto, en el capítulo que antecede al nuestro Almela narra otro caso de "rigurossa justicia" que protagoniza, con curioso paralelismo, el padre del Emplazado, Sancho IV, quien hizo matar cruelmente unos miles de la facción de los Bejaranos, acusados de rebeldía; y los Bejaranos estabi 1 emparentados estrechamente con ramas de la familia Carvajal. El cap. IX, tit. $2^{\circ}$ del L.III recuerda y exalta una empresa de Diego Pérez de Vargas, más conocido como Machuca, empresa no de las más típicas y famosas de este forzudo hombre de armas y que "hubiera sin duda caído en olvido" -en opinión de Amador de los Ríos - sin la publicidad que recibió del Valerio ${ }^{19}$; el tal

17 En el Compendio se trata simplemente de "fiebres".

${ }^{18}$ Que sin embargo recuerda en el Compendio, copiando fielmente la Crónica.

${ }^{19} \mathrm{~J}$. AMADOR DE LOS Ríos, Historia crítica de la literatura española, Madrid, 1865 , t. 7 , p. 313. 
Machuca pertenecía a una rama de los Vargas enlazada con los Carvajales. Para concluir, un par de datos que convendría tener presentes si se quisiera intentar definir mejor el papel del autor en cuanto a rasgos y detalles aparentemente novedosos que nuestro episodio presenta en su recopilación. Desde 1450 aproximadamente, Almela fue arcipreste del Valle de Santibáñez, y como tal se firma todavía en la carta-dedicatoria del Valerio a Juan Manrique en 1462; por esas fechas una hija del Comendador de Santibáñez casaba con Luis de Carvajal, hijo del doctor Garcí López de Carvajal ${ }^{20}$. En Murcia, cuna de Almela, fue corregidor un Diego de Carvajal, con quien nuestro autor tuvo relaciones y al cual envió en enero de 1484 la carta ya citada, donde le daba también noticias de la próxima conclusión del Compendio historial.

Entre 1471 y 1476 se dedica a las viejas historias y a la pluma un magnate de rancia nobleza vizcaína, que avanza camino de los ochenta sin alcanzarlos, con el alma despejada y nostálgica y el cuerpo vejado por la maldad de sus hijos. Las bienandanzas e fortunas no tiene finalidades ni estrictamente historiográficas ni de edificación, aunque informa e instruye como pocos otros libros. Es obra que se complace en primer lugar de sí misma, que se crece encima, que nace y se desarrolla para satisfacer una necesidad incansable de Lope García de Salazar de evocar, revivir y contar un patrimonio de historias y tradiciones, escritas y orales, y de experiencias absorbidas a lo largo de setenta años del siglo $\mathrm{xv}$ y felizmente consignadas a la escritura como un arreglo de cuentas, entre optimista y melancólico, con memorias y mitos de una época en su otoño.

Así relata el emplazamiento y la muerte de Fernando IV:

fuese para la Peña de Martos; e porque le dixieron dos cavalleros que eran Diego de Carvajales e Gonzalo su hermano Robauan e fasían mucho mal, e venjdos allí por mandado del Rey físolos echar de la Peña de Martos. E quando los querían echar dixo el mayor dellos a los que allí estauan: Buenas gentes e Prelados que aquí estades, seredes testigos e diredes al Rey nuestro señor que por esta cruel muerte que nos ha mandado dar sin mereçimjento e sin ser oydos a derecho, que lo enplasamos para ante el Nuestro Señor e Redentor Ihesu Christo que dentro de XXX días paresca antel su soberano juysio e que le damos por fiadores de le complir de dere-

${ }^{20}$ Las informaciones genealógicas se extraen de unos apuntes atribuidos a Lorenzo Galíndez de Carvajal, cf. infra. 
cho a los Apóstoles Sant Pedro e Sant Pablo e que tomamos por nuestro avogado al Apóstol Santiago. E como quier que al Rey fue dicho todo esto por el frayre que los confesó, no se curó dello e luego fueron echados de la Peña avaxo e fisiéronse pedaços. E a cavo de XXX días conplidos comjó el Rey mucho bien al ayantar e echose a dormjr solo en su cama; e así dormjendo llamáronlo aquellos dos hermanos en visión e despertó con grand pavor dando vozes e llamando valedores. $\mathrm{E}$ los que lo oyeron benjeron e falláronlo sin alma boqueando. E así finó este día conplidos los dichos XXX días del plaso ${ }^{21}$.

Este relato nos desplaza de inmediato a otra ladera de la construcción y de la tradición del episodio, la ladera plenamente novelesca y quizás incluso poética en vista de los vínculos tan estrechos que exhibe con los textos romanceriles documentados algunos decenios después, en el siglo xvi. Es común con ellos la acusación de robos y otros desafueros, el tomar la palabra uno de los hermanos y la aparición del discurso directo, la apelación al Juez Soberano con los Apóstoles como testigos y abogados. Fuera de Las bienandanzas no localizo por ahora la aparición de los hermanos difuntos al rey (pero v. infra III3), el violento despertar de Fernando y sus gritos, su quedarse "sin alma boqueando". El texto de Lope García revela un espacio novelesco ampliado en favor de los Carvajales: hablan primero a un coro que es intermediario benévolo entre la autoridad lejana y las víctimas y que se individualiza en el fraile ${ }^{22}$, se presentan en sueños después de

${ }^{21}$ L. García de Salazar, Las bienandanzas e fortunas, ed. A. Rodríguez Herrero, Diputación de Vizcaya, Bilbao, 1967, t. 3, p. 188; sobre autor y fecha véase t. 1, pp. vii ss. y xxiv. Esta edición transcribe un ms. de la Real Academia de la Historia de Madrid, copiado en 1492 del original hoy perdido, cf. t. 1, p. xxvi. El texto que doy ha sido controlado sobre el dicho ms. de la Real Academia de la Historia y sobre el núm. 1634 de la BNM. Para la exposición reciente y rigurosa de los datos relativos al autor y a la obra cf. The legendary history of Britain in Lope Garcia de Salazar's "Libro de las bienandanzas e fortunas", ed. H. L. Sharrer, University of Pennsylvania Press, Philadelphia, 1979, pp. 342. Sería interesante un examen de todos los manuscritos de esta obra. El discurso del mayor de los hermanos volvemos a encontrarlo, resumido y atribuido a ambos, en el f. 243v del ms. 1342 de la BNM, s. XVI, que se presenta como una "Crónica de cuatro reyes" y en realidad recopila y reelabora materiales varios; cf. Gran Crónica de Alfonso XI, t. 1, pp. 28 n, y 65-77. El contacto de Lope García ¿fue directo o a través de una fuente común?

${ }^{22}$ Detrás de este fraile podría sospecharse un historial largo y curioso si, excluyendo la casualidad, lo ponemos en relación con otro fraile, el que sugirió a Alfonso XI la oportunidad de reparar al daño padecido por la familia 
muertos al rey anunciando el cumplirse del plazo. Es el toque final de una trayectoria de martirio y triunfo, en que laten humores hagiográficos. De la enfermedad de Fernando no queda ya ni la sombra que aleteaba todavía en el Valerio y que está bien presente en los romances ${ }^{23}$. Con su ausencia la página de Salazar -y quizás el texto o la tradición que la respalda - ha logrado aligerar de cualquier resabio de "racionalización" un episodio que quiere colocarse sin ambigüedades en la esfera de lo maravilloso y sobrenatural.

Las Crónicas reales, Rodríguez de Almela, Lope García de Salazar, no son tres etapas del acercamiento a esa esfera depura$\mathrm{da}$, sino tres perspectivas parcialmente distintas y diversamente finalizadas, dentro de una cronología muy relativa y difuminada y frente a un "suceso" aprehendido a través de una hoja manuscrita o de una voz que cuenta o canta o mejor, un "suceso" a la vez leído y oído. Cada una de nuestras fuentes corta a su manera el relato del episodio, y si podemos dar por descontado que la segunda y la tercera conocían la primera, o sea la prosa cronística, por muy probable podemos dar también en las tres de una o más narraciones reales, que sólo en las páginas de Lope García

Carvajal, según una tradición recogida - ¿o inventada? - por el ya aludido escritor genealógico atribuido a Galíndez, cf. infra.

${ }^{23}$ Lugar aparte de coincidencias y discordancias sin norma alguna es la esfera de los nombres de los dos hermanos: Diego y Gonzalo en Salazar contra $P e d r o$ y $A l o n s o$ en el Romance según los textos de $G$ y $C a$ (para estas siglas véase infra) y Pedro y Rodrigo según $P$ y $C R$. El Gonzalo de Salazar y el Rodrigo de $P_{1}$ y $C R$ son unicum dentro de la documentación que conozco. Predominan Pedro o Pero y Alfonso o Alonso, emparejados a secas en los textos romanceriles $G$ y $C a$ y en los mss. A y $\mathrm{O}^{1}$, con la variante Pedro Alfonso y Alfonso en la nota marginal de V y en algunas de las referencias de la Genealogía atribuida a Galíndez, o sea en textos todos del s. xvi. En otras partes de la Genealogía encontramos al lado de Pedro ya Diego Alfonso, ya Diego Alonso; y Diego Alfonso con Pero Alfonso están en el ms. M-II-2. En cambio hace pareja con Diego Alfonso un Juan Alfonso en los mss. Z-III-7 y Z-III-12 y en el 10.277. Ese novedoso Juan Alfonso volvemos a encontrarlo tan sólo en Almela, en compañía del corriente Pedro. Más que los nombres, varían las combinaciones, donde descuellan Pedro, Alonso y Diego, o sea los tres nombres que, enlazados de distintas maneras, leemos en la Genealogía. Detectar relaciones entre los textos sobre la base de la onomástica es casi imposible, aunque se puede percibir a veces una huella; por ejemplo la de Almela en G. Argote de Molina, Nobleza de Andaluzia, Sevilla, $1588, \mathrm{I}, 2^{\circ}$, cap. 46 , p. $184 \mathrm{r}$ que trae Juan Alonso y Pedro remitiendo al capítulo 8(?) de una Crónica de Alfonso XI, o en la lápida que en 1595 se colocó en una iglesia de Martos conmemorando el episodio y dando la pareja apenas citada (véase M. Menéndez Pelayo, Tratado de romances viejos, en Antología de poetas líricos castellanos, Aldus, Santander, 1945, t. 7, p. 32 n.). 
- por lo que sabemos - encontraron los filtros más débiles, quizás inexistentes, y así emergieron por fin con toda su crédula novelería. Pero a García de Salazar le bastó abrir la puerta a la novela (granjeándose nuestro agradecimiento), porque a la credulidad la habían abierto ya sus antecesores.

Pero no todos albergaban igual disponibilidad, y desde muy antiguo. Alrededor de medio siglo después de la muerte del rey Fernando, hacia 1362, Ibn al-Jatī anotaba, demasiado velozmente: " Hic [Fernando IV] vero quum extremis eiusdem Regis temporibus [el rey Nassero] arcem Alcaudete circumsederet, fato functus est. Hinc eius corpus, obsidione minime soluta, et morte triduo celata, ad urbem Jaen translatum, donee eius successor plane renunciatus est. Ceterum singularis et scitu sane digna de illius morte fabula narratur, quam nos in Nobilium Virorum Chronologia retulimus"'24. Una traducción castellana, parcial, del árabe suena así: " puso sitio, al fin de sus días, al castillo o plaza fuerte de Alcaudete, en cuyas afueras le sobrevino una dolencia mortal, y fue trasladado desde el lugar del campamento a Jaén", " corre acerca de su muerte una peregrina historia que está contenida en nuestra obra Turfat al- 'Assi' (obra lamentablemente perdida) ${ }^{25}$. La impresión que se saca de esta sucinta alusión es que el historiador granadino, que muy bien pudo tener entre manos una recién escrita Crónica de Fernando IV quién sabe con qué dictado en el segmento que nos atañe, probablemente recogía entre cristianos o quizás también entre musulmanes un relato - oral- que en sus contenidos, y a lo mejor también en su forma, mostraba a las claras ser "fabuloso" y "peregrino". Un texto no necesariamente poético pero sí ya novelesco y dramatizado, un texto frente al cual brotaba espontáneo el divertido escepticismo que se percibe en la frase de Ibn al-Jatī.

También escéptica suena, aunque ya en el campo cristiano,

${ }^{24}$ El latín es, obviamente, el de M. CASIRI, Bibliotheca arabico-hispana escurialensis, Madrid, 1760, t. 2, p. 280; la cita pertenece a la obra Granatae eiusque regum historia, traducción del árabe al lumha al badrîja fî̀ 'd daula an Nașîja, ms. escurialense, $2^{\mathrm{a}}$ ed., 1771, cf. C. BRockelmann, Geschichte der Arabischen Literatur, Berlin, 1902, t. 2, p. 262. A. BenAvides (op. cit., t. 1, pp. 694-695) señaló ya este testimonio a través de Casiri.

${ }^{25}$ M. M. AnTuÑa, "Una versión árabe compendiada de la Historia de España de Alfonso el Sabio", AlAn, 1 (1933), p. 147, n. 2. Es curioso que el renglón saltado por Antuña contenga un detalle ausente en la historiografía oficial; pero no se entiende bien si traduce del Lamhat al-badriyya, como es más probable, o de la Ihāta, recordada también como alusiva a nuestro asunto. 
otra rápida alusión, ésta sí a un texto casi seguramente poético. En el Laberinto de Fortuna (acabado en 1444), la estrofa 287 recuerda a Fernando IV,

del que se dize morir emplazado

de los que de Martos ovo despeñado, segund dizen rústicos d'esto cantando ${ }^{26}$.

Que estos versos nos proporcionen "la primera noticia conocida del romance viejo de los Carvajales', según afirma Menéndez Pidal $^{27}$, es verosímil aunque algo opinable: un texto cantado no debía tener a la fuerza la forma del romance. Pero ya es materia muy opinable inferir de los versos de Juan de Mena que "hacia $1444[\ldots]$ eran los rústicos quienes cantaban el sabido romance de los Carvajales que empieza "Válasme Nuestra Señora""28. En efecto, existía otra versión del Romance, la que empieza "En Alcaudete está el buen rey', que parece documentarse con anterioridad a la antes citada: para su probable transcriptor -el doctor Lorenzo Galíndez de Carvajal, como veremos más adelante- era ésa la aludida por Juan de Mena. No pienso que la indicación de Galíndez pese más que la de Menéndez Pidal, ya que ambos se pronuncian por simple automatismo: el doctor porque se trataba quizás del único texto del Romance que conocía, y en cualquier caso era el que copiaba y quería autorizar, y el filólogo porque "Válasme Nuestra Señora" era la versión más divulgada en las fuentes del siglo XVI y por consiguiente en las colecciones y antologías sucesivas hasta hoy, y por lo tanto la que primero se ofrecía a la memoria ${ }^{29}$.

Lo que se transparenta de los versos de Juan de Mena es que se cantaba un texto, que podemos razonablemente suponer poético; a ese texto Mena parece atribuir la responsabilidad de la divulgación del relato del emplazamiento, de cierto tipo de relato que - por ejemplo- hablaba de "despeñamiento', un detalle que

${ }^{26}$ Juan de Mena, Laberinto de Fortuna, ed. J. G. Cummins, Cátedra, Madrid, 1979.

${ }^{27}$ Ramón Menéndez Pidal, Poesía juglaresca y orígenes de las literaturas románicas, Instituto de Estudios Políticos, Madrid, 1957, p. 322 y n.

${ }^{28}$ Id.; cf. también R. MENÉNDEZ PIDAL, Romancero hispánico, t. 1, p. 311, donde no se da una identidad específica al eventual romance.

29 "En Alcaudete está el buen rey" puede leerse en MenÉndez Pelayo, $o p$. cit., t. 7, p. 26. Existe también la versión del pliego suelto dela biblioteca de la Universidad de Cambridge. Para todas véase infra. 
en la historiografía tiene visos de agregado tardío. Mena conocía demasiado bien las Crónicas y la información de los lectores de su Laberinto para cometer el error de indicar en el texto cantado la única fuente que atestiguaba el episodio. $\mathrm{Si}$ a él quiso remitir, y por algo más que no fuera el simple gusto de evocar una tradición mitopoética nacional como a su manera podía ser también la popular, es posible pensar que obedecía o bien al convencimiento que la tradición cantada estaba a espaldas de la prosa histórica, o bien a la intención de calificar al episodio de patraña corriente entre el vulgo, con una censura implícita a las Crónicas. La primera hipótesis, quizás un tanto anacrónica por su matiz de filologismo, no excluye la segunda, que me parece más plausible y que interpreta mejor la distanciación respecto al episodio marcada con "se dize" y "dizen rústicos".

El poeta cordobés y el erudito granadino, el cristiano por un lado y el musulmán por el otro, coinciden en un asomo de conciencia crítica y - ¿por qué no? - laica; a lo mejor el texto que el uno había oído cantar coincidía con el de la "fábula singular" que el otro había oído contar. Si lo sintético de las alusiones de ambos ha podido engañarnos, dejémonos engañar una vez más por otro personaje que parece apuntarse en la lista de los escépticos. En los mismos años en que escribe Mena su poema, Juan de Salzedo redacta una nota donde señala los huecos observados en un ms. de la Crónica fernandina (v. supra). Para la zona que nos atañe, alude a "los dos escuderos" mandados despeñar y a "como murio el rey de dolençia"; no hay huella ni del emplazamiento ni de su conexión con la muerte de Fernando. Lo concentrado de la nota de Salzedo no es impedimento para dar un sentido a su silencio sobre el lugar común que ya entonces era la modalidad de una muerte que en la "dolençia" había tenido tan sólo una causa marginal.

Dos prosas historiográficas de la segunda mitad del siglo nos muestran cómo podían conjugarse brevedad y respeto - e incluso realce, a costa de las justas proporciones- del tópico, dejando traslucir también cierta incredulidad, por lo menos en un caso, el primero. Hacia 1470 Pedro de Escavias dedica el cap. CXL de su Repertorio de principes a Fernando IV, por un total de diecinueve renglones, de los cuales ocho tratan exclusivamente de la circunstancia de la muerte:

Algunos dizen que la ocasión de su muerte fue porque mandó despeñar de la Peña de Martos a dos escuderos hermanos que se lla- 
mavan de Carvajal los quales, al tiempo que despeñallos quisieron, dizen que enplaçaron al rrey que, fasta treynta días, ante Dios Nuestro Señor pareçiese con ellos, en el qual plaço murióo ${ }^{30}$.

La apretada iteración de "dizen" nos recuerda la fórmula y la distanciación de Juan de Mena. Sin embargo, en la fraseología resuena la prosa de las Crónicas. Sorprende, entonces, la falta de un detalle esencial antes de "mandó despeñar" o allí donde las víctimas pronuncian el emplazamiento: la alusión a lo injusto de la condena mediante una expresión del tipo "a tuerto". Falta también en Mena, pero la suya era una obra poética y sus pocos versos no querían ser nada más que un epíteto glosado; la ausencia en una recopilación histórica se matiza de anomalía ${ }^{31}$. Mosén Diego de Valera, por ejemplo, que redacta entre 1479 y 1481 una sucinta Crónica de España, le reserva a Fernando IV el capítulo 115, de medida más o menos correspondiente a la del capítulo de Escavias: veintidós renglones. La muerte del rey llega a ocupar nueve de ellos, y se informa que murió emplazado "por dos escuderos llamados carauajales que a tuerto mado matar' .Es más: el título del capítulo reza: "del rey don fernando quarto $\overline{\mathrm{q}}$ murio en Jaen emplaçado por dos hermanos caravajales q a tuerto mandó matàr'"32. Si es la fórmula que se impone por la fuerza de su propia inercia, cabe preguntarse por qué esa fuerza no actúa en la prosa de Escavias, que a las fórmulas no era insensible. No creo que el alcalde de Andújar estuviera convencido de la culpabilidad de los Carvajales; más simplemente me inclino a pensar que no le apetecía dejar constancia en sus páginas de la inocencia de los dos hermanos. Y esto más por sugestiones del presente que por ciencia del pasado. Pero será mejor abrir otro párrafo.

En los Hechos del condestable Miguel Lucas de Iranzo, redactados quizá entre 1473 y 1474, encontramos más de una referencia a dos hermanos Carvajal. No se trata, desde luego, de los supuestos emplazadores de Fernando IV sino de otra pareja que actúa

${ }^{30}$ M. García, Repertorio de príncipes de España y obra poética del alcaide Pedro de Escavias, C.S.I.C., Jaén, 1972, p. 274; para la fecha cf. p. liii.

${ }^{31}$ En ibid., pp. lxix y 439, se comprueba la imposibilidad de individuar las fuentes del cap. sobre Fernando; en la p. 274 n., se atribuye su brevedad a la probable falta de "fuentes accesibles" a Escavias.

${ }^{32}$ M. D. De Valera, Crónica de España, Burgos, 1487, ff. 161v y 162r. En A. DE BEnAVides, op. cit., t. 1 , pp. 686-696 se encuentra una larga reseña de alusiones a nuestro relato, casi todas del s. XVI en adelante. 
en los decenios centrales del siglo xv: Diego de Carvajal y su hermano Juan de Mendoza, por apellido materno, comendador de la Peña. Esta Peña es, obviamente, la de Martos y en su territorio y en el de Baeza ambos hermanos desempeñan un papel relevante, aunque secundario, en enfrentamientos y escaramuzas, actuando con rasgos de ambigüedad que dejan siempre sospechosos a amigos y enemigos. Así, por lo menos, es como los presentan los Hechos. Primero sale a escena Diego, privado del Maestre de Calatrava don Pedro Girón, sublevado contra Enrique IV y dedicado a asolar el territorio de Jaén con el intento de desbaratar y eliminar a Lucas de Iranzo. A Diego Carvajal le encarga el Maestre el sitio del castillo de Belmes, pero el asedio falla por la llegada del Condestable. Esto en 1464. El año siguiente Diego y el hermano intentan asaltar a dos hermanos de Iranzo que acompañan a doña Elvira de Narváez y pasan cerca de Martos; otro fracaso. En 1466, al morir el Maestre de Calatrava, "Diego de Caruajal e Juan de Mendoça su hermano, sus criados, quedaron y estauan apoderados en la çibdad de Baeça y su alcaçar, con otros de su maluada opinión, contra el dicho señor rey"; pero un acuerdo secreto entre Diego y su cuñado Juan de la Cueva promete la rendición a Iranzo, a quien, sin embargo, llega también la información que Diego no piensa respetar el pacto. Poco tiempo después el marqués de Villena, don Juan Pacheco, ahora partidario del príncipe Alfonso, "por sospechas que avía de Diego de Caruajal, que tenía el alcáçar della [Baeza], y del comendador Mendoça su hermano, e por cosas que dellos le decían, prendió al dicho Diego de Carvajal, en la posada de su madre"; el hermano, "que tenía la villa e castillo de Martos e la Peña, alçóse con todo ello [... ] e tomó la boz del señor rey don Enrrique." La madre de los Carvajal se refugia en Jaén, en casa de Iranzo, que envía refuerzos a Martos. Sin embargo, al conseguir Diego escaparse y reunirse con el hermano, ambos acaban aviniéndose con Villena y le entregan la villa y el castillo de Martos, declarándose contra Enrique IV. Esta secuencia de "empresas" se cierra con la sugerencia del comendador de la Peña a don Alonso de Aguilar, deseoso de hacer daño al rey de Granada, de entrar contra los moros de Guadix, estragar la tierra y llevarse algunos miles de cabezas de ganado. Poco antes que acometan la acción, el comendador aconseja renunciar por el mal tiempo; pero parece que otro hermano suyo, Día Sánchez de Carvajal, había avisado al caudillo de Guadix, con quien tenía buenos tratos. Por otra parte, el conde de Cabra, adversario de Alonso de Aguilar, parece que también le 
había avisado al rey de Granada, su buen amigo ${ }^{33}$. Para la época y el ambiente de la frontera, conductas como las de estos hermanos Carvajal no sorprenden; tampoco sorprende el evidente encono que les tiene el apologeta del condestable Iranzo. Ese encono es superior al que demuestra - por tener menos ocasiones, quizá- hacia otro prócer de Baeza y rebelde contra el rey Enrique pero.jefe de la familia adversaria local de los Carvajal: se trata de Juan de Benavides, primo carnal de Jorge Manrique, que en los sucesos de la época tuvo un papel mucho más relevante que el de los Carvajal ${ }^{34}$. Los retornos de la Historia, con la complicidad de la onomástica y de las rencillas en las tradiciones familiares, nos deparan frente a frente una vez más dos hermanos Carvajal y un Juan de Benavides, como en el relato del emplazamiento según algunos mss. de las Crónicas. Benavides por un lado y Carvajales y otras familias por el otro protagonizaron las discordias y refriegas locales de Baeza a partir de 1436: con optimismo de erudito señala ese año, más simbólico en la historia de añejos rencores, el analista eclesiástico del obispado de Jaén Jimena Jurado, que escribía en el siglo XvII ${ }^{35}$. Lo enraizado de esos rencores nos lo confirman un par de notas marginales del ms. del siglo $\mathrm{Xv}$ de los Hechos. Dice la primera: "De cómo Juan de Venauides fué deseruidor a su rey $[\ldots]$ "; y la segunda, más sabrosa: "Esta glosa

33 Cf. la ed. de los Hechos por J. de Mata Carriazo, Madrid, 1940, pp. 256, 263, 313, 326-327, 443 y 447. La autoría de los Hechos es cuestión debatida y no resuelta: aparte de la Introducción de Mata Carriazo, cf. en particular M. García, op. cit., pp. cvii-cxiv y "A propos de la chronique du Connétable Miguel Lucas de Iranzo", BHi, 75 (1973), 5-39, que la niega, mientras J. B. Avalle-Arce, El cronista Pedro de Escavias. Una vida del siglo xv, University of North Carolina Press, Chapel Hill, 1972, pp. 107-136, que la afirma, reforzando argumentos de Mata Carriazo. Las probabilidades de Escavias son equivalentes a las de los otros candidatos a la autoría, los cuales - sin embargono pueden alegar probanzas de tipo literario como hace Escavias; sólo que esos materiales demuestran todo lo contrario; cf. las documentadas e ingeniosas investigaciones que acabo de citar y otras que en ellas se exponen. A efectos de mi párrafo, los Hechos se alegan como testimonios de los humores de un hombre, su autor, pero en cuanto partícipe de los humores de un partido; lo que refieren sobre los Carvajales y cómo lo refieren puede provenir como escritura de las manos de Escavias o de las de los secretarios de Iranzo, como espíritu pertenece al grupo. Por lo demás, un nieto del alcaide de Andújar casará con una Isabel de Carbajal y Mendoza, tal vez nieta del Comendador de la Peña; cf. la tabla genealógica en J. B. Avalle-Arce, op. cit., p. 150.

${ }^{34}$ A. Serrano de Haro, Personalidad y destino de Jorge Manrique, $2^{\text {a }}$ ed., Gredos, Madrid, 1975, pp. 181 ss.

${ }^{35}$ Ibid., p. 183. 
[la primera] es de Juan de Caruajal, vecino de Baeça, cuyo fué este libro y es la letra; y era enemigo de los Benauides y Quesadas, porque tuvieron a pique de ahorcar al arcediano su hermano o tío" 36. Desde luego, entre los Carvajal era más bien corriente la afición a los papeles históricos y a su anotación más o menos interesada.

Creo que lo que acabo de exponer estimula una sospecha: ¿pudieron las rivalidades baezanas y el arraigado antagonismo entre Benavides y Carvajales sugerir la identificación con dos Carvajal de los dos caballeros hermanos de tiempo de Fernando IV acusados del asesinato de un Juan de Benavides? Si original puede ser mi sospecha, tal no es el evocar las banderías de Baeza al tratar del emplazamiento del rey Fernando. Lo hizo ya, obviamente, un Carvajal, el más adicto de todos a buscar, leer, anotar, redactar - y un poco manipular - crónicas, relaciones, esbozos genealógicos: el doctor Lorenzo Galíndez. En una Genealogía de los Carvajales que se le atribuye, anotó, comentando el suceso del xiv: "y teniendo los de Caruajal con los de venavides grandes diferençias, y vandos, y por el contrario, como oy los ay en Baeça" (v. infra). Es difícil averiguar si la enemistad de hogaño llevaba a Galíndez a dar por descontada una enemistad de antaño, o si conocimientos suyos de esta segunda le inducían a emparejarla con la primera y contemporánea. Tal duda es como un apéndice a la sospecha antes apuntada, a la que agrego un codicilo más. El reto que enfrentó a los dos Carvajal con el tal Benavides lo cuenta Galíndez en más de una versión; en una el adversario es llamado "Pedro Buron de Benavides"37. Es la misma denominación que hemos encontrado en el ms. V de la Crónica fernandina, en la ya citada nota marginal que además de éste tiene otras coincidencias con Galíndez: los mismos nombres para los dos hermanos, la alusión al reto en Valladolid cerca de la Puerta que desde entonces se llamó del Campo y la degollación antes del despeñamiento. Volviendo a "Burón", recuerdo que en otro texto que relata la misma versión se le cita como "Urones" 38 : las tres fuen-

${ }^{36}$ Hechos del Condestable, p. 254; cf. también p. xv. Avalle-Arce op. cit., p. $108 \mathrm{n}$., cree poder identificar a este Juan de Caruajal con un "tataranieto de Pedro de Escavias" que fue regidor de Baeza, pero pienso que nos llevaría demasiado lejos (unas cuatro generaciones) respecto al ardor de las luchas y rencores que las notas delatan.

${ }^{37}$ Cf. las pp. 669 y 672 del texto de la Genealogía, cit. infra nota 43; en la p. 666 menciona a Día Sánchez de Caruajal, nombrado en los Hechos, y a otros Carvajales de Baeza.

${ }^{38}$ En el Blasón y recogimiento de armas de García Alonso de TORRes, f. 189v; cf. infra la n. 65. "Urones" o "Hurones" era un linaje. 
tes son de finales del siglo xv y comienzos del xvi. ¿Por la estrecha afinidad de sonidos, esos "Buron"'-Urones" podrían asociarse a "Serones"? "Los Serones" era el nombre que tenían en el siglo Xv los Benavides en Baeza ${ }^{39}$. En una tradición oral, nada más fácil que el pasar de "los Serones" a "los erones" a "los urones" y a "uron" para un solo individuo del clan.

Quede apuntada ésta junto con otras sendas en el boscaje de los textos y de la historia. Todas habrá que explorarlas antes de sentenciar sobre lo certero o lo engañoso de la una o de la otra.

Fue Menéndez Pelayo el primero en aprovechar un extracto de la Genealogía de los Carvajales, atribuida a Lorenzo Galíndez de Carvajal, para ilustrar el Romance sobre la muerte de Fernando IV ${ }^{40}$. Se trata de un testimonio tan interesante como problemático. Dicho extracto lo había publicado más ampliamente $\mathrm{Ba}$ rrantes, fuente de Menéndez Pelayo, y era copia sacada por un archivero de un ms. del siglo Xvi de la Catedral de Toledo: "un códice en $4^{\circ}$, sin principio ni fin, de letra muy metida, y al parecer del siglo xvi", agregándose que "los escasos cuadernos que se pudieron coordinar contenían documentos y noticias de la mayor importancia"41. Actualmente este ms. no se localiza. En él se contenía el texto del Romance, del cual lamentablemente el archivero copió para Barrantes sólo los primeros cuatro versos. Difieren un poco de los correspondientes en un texto del Romance que años después publica Hurtado, quien parece usar un ms. de la Genealogía diferente del toledano - a juzgar por los versos-, pero quizá distinto también del que citaré en seguida, en el que no encuentro la única frase transcrita por Hurtado, aunque sí coinciden los dos textos del Romance ${ }^{42}$. En 1953 Rodríguez-Moñino publica la transcripción de un ms. de su propiedad sobre la "desçendençia del linage y casa de Carauajal" que "escribio el doctor

${ }^{39}$ A. Serrano de Haro, op. cit., p. 183.

${ }^{40}$ M. Menéndez Pelayo, op. cit., t. 7, pp. 25-26 y 31 n. En la p. 26 n. observa que "no debe de ser el primitivo trabajo de Galíndez sino interpolado por un genealogista posterior".

${ }^{41}$ Informe de José Foradada, del cuerpo de Archiveros y Bibliotecarios, dado en 1874: V. BARRANTES, Aparato bibliográfico para la historia de Extremadura, Madrid, 1875-1877, t. 3, p. 46. Foradada vio el ms. en el Archivo de Toledo, donde había llegado de la Catedral en 1869 a consecuencia de la incautación; fue devuelto después al Cabildo.

42 P. Hurtado, "Los Carvajales", Revista de Extremadura, 1902, núm. 4, 324-332, en especial p. 328. Este texto del Romance es el que reimprime M. Menéndez Pelayo, op. cit., t. 7, pp. 26-27. 
Lorenço Galindez de Caruajal', según rezan los primeros renglones de una especie de breve presentación. El erudito bibliógrafo informa que se trata de una "copia hecha para D. Íñigo Antonio de Argüello Carvajal en la primera mitad del siglo XvII" y cree "que la primitiva redacción ha sido interpolada y añadida en fecha muy posterior al fallecimiento de su autor", remitiendo a un futuro análisis, desafortunadamente no realizado ${ }^{43}$.

Resumiendo: en la actualidad disponemos de un texto "entero" de la llamada Genealogía de los Carvajales, el que denomino GenRM ( = Rodríguez-Moñino); del extracto de un ms. extraviado, la $\mathrm{Gen} B$ ( = Barrantes); de la indirecta suposición de otro ms., el utilizado por Hurtado. Un cotejo entre $G e n B$ y las partes correspondientes de GenRM muestra cómo el primero es una relaboración y un redondeamiento de un texto no muy distinto del segundo; GenRM es muy rudimentario y sin duda más arcaico, y abriga materiales que pudieron ser originarios del doctor Galíndez e incluso en la misma forma provisional en que los había redactado y juntado.

Consideremos en primer lugar la fecha de estos apuntes. La de 1506 que vulgarmente corre es insostenible a la luz del único texto que de momento se conoce, o sea GenRM. En éste se registran tres fechas: 1506 ("este presente año"), 1520 ("el año pasado de mili y quinientos y veinte"), 1524 ("'este año"); se remite también a sucesos fácilmente fechables: las Comunidades (1520-21), Carlos V emperador (post 1520), la batalla de Pavía (1525) y el De hispanorum nobilitate de Juan García de Saavedra (1588), obra citada en el párrafo que antecede al colofón que reafirma la autoría de Galíndez ${ }^{44}$. Salvo esta última fecha, todas caen antes de

${ }^{43}$ A. Rodríguez MoÑino, "El Memorial de los Carvajales del Dr. Galíndez de Carvajal", $R E E, 1951$, núm. 7, p. 655 y n.; el texto en las pp. 655-692. Existe tirada aparte, Badajoz, 1953. He controlado directamente sobre fotocopias del original las zonas de este ms. más relacionadas con nuestro asunto y todo cuanto he transcrito de ellas, inclusive el texto del Romance. A la intuición y a la cortesía de doña María Brey debo también la fotocopia de un fragmento de una carta de Argüello a Diego Vargas Hinojosa, fechada en Badajoz, 20 de enero de 1651, de la cual no tenía noticia y donde se afirma la total falsedad del Memorial y lo arbitrario de su atribución a Galíndez: "no lo escribio el dicho Dotor, Antes Algun grande Enemigo suyo y de su nuera"; y se avisa: "son tantas las anotaciones que le tengo hechas que si se vieran a la margen, quedava sin credito $\mathrm{El}$ tal memorial". En las hojas que he podido controlar hay notas marginales integrativas de Antonio de Monroy y de Chavista, pero ninguna relativa a la parte del texto que nos atañe.

${ }^{44}$ Las citas de GenRM provienen, en el orden en que las he expuesto, de 
1528, año de la muerte de Galíndez, y por lo tanto los materiales que las contienen podrían ser de manos del doctor. Teniendo en cuenta la definición que acompaña las primeras tres fechas, podríamos pensar en tres momentos por lo menos en los cuales $\mathrm{Ga}$ líndez trabaja en su "memorial" o redacta sus fichas. Pero en GenRM estos tres momentos están lejos de sucederse en el orden debido, como muestra claramente mi referencia a sus páginas. Es evidente que GenRM se presenta como un conjunto de apuntes o como el resultado inacabado del desmembramiento de un texto anterior y de una actividad de taracea, amplificación y manipulación ingenuamente autorizada en sus últimas hojas con esta afirmación: "Finis genealogi huius Dictae Laureçii Galindez de Caruajal consiliarii, et Refrendarii imperatoris Caroli quinti" "45, que bien pudo ser colofón de un texto primitivo.

Otros elementos refuerzan estas dudas. En las primeras hojas encontramos citas de sucesos y personajes que se dan como tratados anteriormente, con expresiones del tipo "como es dicho" o "desuso sse toco"; pero nada se halla en las hojas que anteceden. Algunas confusiones o contradicciones inducen a pensar en manos distintas; por ejemplo, en la p. 671 se lee: "con quien fue casada Seuilla Lopez no soi acordado", cuando en las pp. 663 y 664 se registraba a Alonso García de Vargas como su marido; en la p. 684 se da como "hulana Galíndez" a quien en la p. 658 se ha llamado Catalina González Galinda; etc. En la p. 688 el párrafo queda trunco y empieza otro con una sintaxis distinta, plagada de anacolutos.

las pp. $671,677,656,658$ y 680,662 y 690 . La fecha de 1506 para el escrito genealógico de Galíndez la divulgó R. Floranes, Vida y obra del Dr. D. Lorenzo Galíndez Carvajal, en la Colección de documentos inéditos para la historia de España (CODOIN), t. 20, Madrid, 1852, pp. 279-406, v. esp. p. 281, apoyándose en fray Alonso Fernández, Historia y Anales de la ciudad y obispado de Plasencia, Madrid, 1627 (existe una ed. de Cáceres, 1952): en la p. 10 se cita la Genealogía entre las fuentes. Florantes no la vio nunca. Es muy probable que Fernández manejara un texto distinto de los que conocemos; su frase es: "En todo lo que se escrive de los Carvajales hasta el año mil y quinientos y seis seguimos al Doctor Lorenço Galindez de Caruajal", apud, J. Torres FonTES, Estudio sobre la "Crónica de Enrique IV' del Dr. Galíndez de Carvajal, Murcia, 1946, p. 21; de la p. 21 a la 26 se traza un enjundioso esbozo biográfico y literario de $\mathrm{Ga}$ líndez, con una lista de sus numerosos escritos, entre los cuales hay unas "Adiciones" a Los linajes de España de LOPE GARcía de SALAZAR que merecería una ojeada.

${ }^{45}$ GenRM, p. 691 . Siguen un par de hojas con una escueta lista de la "Casa de los señores de la higuera de Vargas". 
Las indicaciones de fechas y el cómputo de años causan perplejidad en demasiadas ocasiones en una obra de este tipo, atribuida además a un cultivador casi maniático de crónicas y viejos papeles, por gusto y oficio, como fue el doctor Galíndez, autor seguro de muchas relaciones históricas que en gran parte yacen manuscritas y de quien Floranes afirma se dedicó "á recoger todo género de monumentos antiguos, inscripciones, privilegios, diplomas, manuscritos, memorias, piezas de legislación, etc., para documentar su obra" 46 . Sorprende que un Galíndez tuviera que dejar en blanco el espacio para el día y el mes de la muerte de un personaje como el cardenal de Santa Cruz, don Bernaldino de Carvajal, fechándola además en 1524 cuando había ocurrido en 1523 , como apunta exactamente en otra obra ${ }^{47}$; o que colocara el emplazamiento y la muerte de Fernando IV en la era de 1410 " $p o c o$ mas o menos", cuando habría tenido que escribir 1350; o que dejara en blanco incluso la centuria para la fecha del comienzo del reinado de Sancho IV, quedándose en "era de mili, y"; o que diera "quinçe años" de reinado al mismo Sancho cuando fueron once, y "onçe" a Fernando cuando fueron diecisiete, y a Alfonso XI "treinta y tres poco mas, o menos" en vez de treinta y ocho, sumando un total de "setenta años poco mas, o menos" mientras se podría oscilar entre ciencuenta y nueve y sesenta y seis, según se consideren las épocas de menor edad ${ }^{48}$. Esa curiosa fórmula "poco mas o menos", tan impropia de un erudito como nuestro doctor y que encuentro cinco veces en las primeras catorce páginas de $\operatorname{Gen} R M$, no aparece ni una sola en obras ciertas de Galíndez como los Anales breves o las Adiciones genealógicas, escritos repletos de fechas, en su mayoría de poca monta ${ }^{49}$. Podríamos hablar de una mano caracterizada por ese "poco mas o

${ }^{46}$ R. Floranes, op. cit., p. 394.

47 En los Anales breves del reynado de los Reyes Católicos (el título original es Memoria o registro breve de los lugares donde el Rey y la Reyna Católicos [. . . ] estuvieron cada año desde el de 1468), en CODOIN, t. 18, Madrid, 1851, p. 275, donde se da el día, 16, y el mes, septiembre, pero fue diciembre. Hay que decir que esta obra se conserva en un ms. que es copia de copia, como declara una nota: "Este traslado se saco de otro que hizo Luis de Carbajal por mandado del ilustre Señor D. Bernardino de Mendoza, Señor de las villas de Griñon y Cubas, y le acabo a 2 de octubre de 1553 ", ibid., p. 420.

48 GenRM, pp. 669-670.

49 Adiciones genealógicas a los claros varones de Castilla de Fernan Perez de Guzman [...] escritas [...] en el año 1517, en CODOIN, t. 18, pp. 423-563. Notas a pie de página en la edición de estas obras señalan algunas equivocaciones, pocas en relación con la cantidad de datos en ellas acumuladas. Dejar espacios 
menos". Cuando en la p. 670 se recuerda una ejecutoria concedida por Pedro I, era de 1391, o sea año 1353 (confirmado más adelante, p. 681: 29 de diciembre del año 1391 de la era), se afirma que "hasta este presente año de mili, y quinientos, y seis" han pasado ciento y ochenta y tres años; tal dato nos lleva, sin embargo, a 1536. ¿Simple descuido o delación involuntaria de la época de ésta y quizás de otras interpolaciones?

A este propósito analicemos unos renglones dedicados a Carlos V: "Tambien quando el emPerador Don Carlos nuestro señor Rey despeña, y de Alemania, y Flandes etcetera sse fue a coronar [blanco] en el año pasado de mill y quinientos, y veinte, Donde rreçiuio la primera corona Martes veinte y tres de octubre conçedio el Dicho Doctor Caruajal su refrendario, y de el su consejo que por lo que alli le siruio, que pudiesse traer el, y sus desçendientes por Armas, o deuisa como quisiesse junta y apartadamente con las Armas de Caruajal el Aguila imperial como la traen" 50 . Es muy probable que en el espacio blanco debiera escribirse el nombre del lugar donde Carlos fue coronado, o sea Aquisgrán, ya que ese 23 de octubre de 1520 es la fecha de la coronación imperial; y ésta no representó la "primera corona", la cual había sido la de España, recibida en Valladolid a comienzos de 1518. Es muy poco verosímil que la omisión y la equivocación fueran de aquel Galíndez que amplia parte tuvo en los acontecimientos de esos años, como probaría la misma distinción que parece haberle otorgado Carlos, lo hiciera o no el día solemne de Aquisgrán, donde Galíndez de todas formas no asistió, aunque la frase antes citada parece dar a entender otra cosa. Evidente en la frase es la intención de dar un marco de gran realce a un elemento del blasón de una rama de los Carvajales; intención que parece animar la pluma más bien de un descendiente de nuestro doctor, según se podría inferir del "como la traen" final y de los descuidos señalados ${ }^{51}$. Galíndez tuvo cuatro hijos, pero sólo a uno

en blanco durante la redacción de un escrito erudito era práctica corriente, aplicada también por Galíndez; consta en su trabajo de anotación y preparación editorial de los Claros varones, donde es necesario "llenar los huecos de nombres y apellidos que dejó en blanco", según avisa R. FLORANES, op. cit., p. 380. Para la GenRM, blancos y yerros pueden ser consecuencia también de una transmisión larga y accidentada.

${ }^{50}$ GenRM, p. 677.

${ }^{51}$ A propósito de la expresión "el año pasado", es oportuno tener en cuenta que no siempre debe referirse al año que inmediatamente precede la fecha en que se escribe. En las Adiciones, obra compuesta en 1517 según se de- 
se le menciona en GenRM, y desde luego es el primogénito: “Deste Señor Don Diego Gonçalez de Caruajal es hijo el señor Doctor Lorenzo Galindez de Caruajal, y de este es hijo el señor Diego de Vargas, y caruajal'"52. Estos renglones se leen en una zona del ms. que presenta el aspecto de un agregado y que empieza en la p. 681 con la apretada exposición de la genealogía desde Álvar García, que en la primera página era "de Orellana" y ahora es "Bejarano", repitiendo sintéticamente, pero con variantes y confusiones, la mayoría de los datos ya expuestos en las páginas iniciales. Esta especie de segundo escrito genealógico parece desarrollo de la rama que empalma con los Vargas y pudo muy bien correr a cargo del aludido primogénito de Galíndez, que sospecho como primer organizador de eventuales fichas sueltas del padre y como discreto administrador de la autoridad implícita en el nombre del doctor.

Es cierto que los hijos de Galíndez conocían y custodiaban bien los papeles del padre, tanto que en 1544 las Cortes de Valladolid instaron al emperador para que procediese, con la finalidad de imprimirlos, a una adquisición o quizás incautación de aquellos volúmenes de leyes y premáticas reunidos por Galíndez según un proyecto de la reina Isabel: "somos certificados que sus hijos tienen estos libros", se afirmó en las Cortes ${ }^{53}$. La afición a las memorias históricas y a la pluma glosadora dentro del amplio clan de los Garvajales hemos podido rastrearla incluso recorriendo nuestro reducido campo: recordemos la nota en el ms. P de la Gran Crónica de Alfonso XI, la nota en el ms. de los Hechos del Condestable Iranzo, la copia del ms. de los Anales breves, las vicisitudes de esta misma Genealogía con sus apostillas y la carta ya citada.

Con la experiencia y el recelo que nos vienen de las consideracio-les que anteceden, posemos nuestros ojos sobre las páginas de GenRM relativas a los dos hermanos ajusticiados en Martos.

clara, "el año pasado"' indica 1515 (p. 535), 1512 (pp. 435 y 464) y hasta 1493 (p. 496). Naturalmente se puede pensar en fichas y apuntes redactados a lo largo de los años y en 1517 reunidos, método de trabajo muy probable para un curioso anotador y recopilador como Galíndez, llevado también por sus encargos oficiales a manejar un archivo de documentación suelta acumulada en el tiempo.

${ }^{52}$ GenRM, p. 684.

${ }^{53}$ R. Floranes, op. cit., pp. 345 ss. y J. Torres Fontes, op. cit., pp. 2122 , quien subraya el celo con que el hijo cuidaba de la propiedad intelectual paterna de tales materiales. 
Las prepara un relato que arranca desde "Diego Gonçalez de Carauajal el qual vino primeramente de Leon [...] a poblar la ciudad de Plasençia, que lo truxo el rey don Sancho segun la opinion de muchos", para llegar a un Carvajal muerto en la batalla de Pavía, perfilando así ejemplos de estrecha vinculación de estos caballeros con la corona; fidelidad que ya Sancho galardonó con la privanza acordada al tal Diego González (pero aquí se embrollan nombres y generaciones) y un aumento "de tierra lo que es entre tejo, y el rrio Almonte, y otras muchas heredades". Sobre todo se subraya que "destos Caruajales vienen los que son mas antiguos Caruajales en la ciudad de Plasencia, aunque muchos de ellos no son oy tan rricos, ni principales como los que desçienden por liña dle mugeres", o sea la línea de Galíndez. Se pondera, en fin, el desconocimiento recíproco entre tantas "liñas" derivadas de una cepa común, y se recuerdan en particular a los Carvajal de Baeza y Úbeda, descendientes de ricoshombres allí llegados con Fernando III. Y sigue:

tornando al proposito de los que fueron despeñados es de uer lo siguiente [empieza otro párrafo, bien separado] Y como las mas veçes acaeçe que los que som [sic; es corriente] mas açeptos, o priuados de los padres no lo son de los hijos subçedio que despues de la muerte del Rey Don Sancho heredo los Reynos el Rey Don Fernando quarto su hijo, el qual segun diçe mando degollar, o despeñar como se cuenta [blanco] como se quenta a los dos caualleros hermanos caruajales Pero Alonso y Don Diego Alonso su hermano de la Peña de Martos la causa de haçer el Rey esta justiçia absoluta se cuenta de Muchas maneras vna cuenta el rromançe antiguo, a que Joan de Mena en sus tresçientas dixo rrustico cantando porque se canto por todos los de los Reynos largos tiempos asta tanto que vino a las aldeas, y rrusticos no emBargante que aun en nuestros tiempos la Reyna Doña Ysabel de gloriosa memoria creia que no ofendia a su autoridad en lo oir con atençion et qui videt [blanco] [empieza otro párrafo] Porque en la verdad lo que subçedio en la muerte del Rey Don Fernando fue cosa, que puso admiraçion; aunque si ello fue por aquello; o por otra causa solo dios lo saue por el rromançe Parece que les imponia auer hecho malfetuas por el Reyno; pero quellos las ouiesen hecho no paresçe antes paresçe por el Romançe lo contrario. el Romançe es a la letra el que sse sigue [texto del. Romance: $v$. infra] Y Por eso creem muchos que aquella que el Romançe quenta que se les imponia mas fue achaque que la causa, Otros diçen juntando lo que la Choronica del Rey Don Hernando siente con lo que paso en aquel tiempo la causa fue questos caualleros asi caruajales como venavides tenian sus asientos, y viuiendas de luengos tiempos en Valen- 
çia, que mucho después se llamo Valençia de Don Joam porque [ . . . ] y teniendo los de Carauajal con los de venavides grandes diferençias, y vandos, y por el contrario, como oy los ay en Baeça diz que se rretaron, y el rreto se uino a concluir ante el Rey, y diçen algunos que el rreto fue entre Pedro de Caruajal, y Pedro Buron de Venavides, este primer rreto diçen otros que fue dos por dos de la una parte Pedro Alfonso y Diego Alfonso de Caruajal hermanos, y de la otra Pedro Buron de Venavides, y su hijo, otros diçen queste Pedro Buron no era del linage de Venavides. Otros diçen queste primer rrepto fue entre dos caualleros de Caruajal con otros dos de los Couiles pero lo que mas se cree es que fue con los de Venavides este trançe con quienquiera que fuesse es çierto que paso en Valladolid a la puerta, que oy por aquella causa, y prinçipio se llama la puerta del Campo, en el qual entrambas partes sse ouieron a muy esforçada, y valientemente, y a la fin los de Caruajal vençieron el campo, y cortaron la cabeça a sus enemigos de lo qual diçen algunos que subçedio adelante questando en Palençia el Rey Don Fernando quarto hijo del dicho Rey Don Sancho fueron rreptados estos caualleros de Caruajal porque parcçe que vna noche tarde saliendo de palaçio Joan Alonso de Venauides fue muerto, y esta muerte fue imputada a los de Caruajal por ser enenigos, y asi lo creio el Rey Don Fernando, y sin sauer la verdad, ni examinarla ni les haçer proçeso de justiçia, y dando fe a sus enemigos los hięo justiçiar; pero si fueron despeñados viuos, o los degollaron primero poco haçe al caso de sauer pues padeçieron la Choronica presuponesse que fueron degollados, y el Romançe que fueron despeñados todo pudo ser, [...] esto paso era de mill, y quatroçicntos, y diez años poco mas o menos. estos caruajales eran dendos muy cercanos de los de Plasençia $[\ldots]^{54}$.

El "tornando al proposito" del exordio no tiene sentido en el texto de GenRM, que en ningún lugar anterior trata de los dos hermanos despeñados. El relato que he transcrito se presenta como una inesperada y magna amplificación injertada un poco bruscamente en esa zona, aprovechando la referencia a Sancho IV y a su favor para con los Carvajal y creando un fuerte contraste con la muy distinta actitud de su hijo Fernando. A su vez contrastan con ella las grandes mercedes que Alfonso XI otorga a los descendientes de los despeñados y que se relatan seguidamente, pero después de haber expuesto otra versión del desgraciado suceso. Dentro de la estructura y de la manera expositiva de GenRM el trecho relativo a los dos hermanos aparece fuertemente desproporciona-

${ }^{54}$ Ff. [5r-6r] del ms. y pp. 666-669 de la ed. cit. 
do y anormal; pero, enmarcado como está entre el tangible favor de dos monarcas, este segmento turbio de las vicisitudes de la gens acabá proyectando la luminosidad del sacrificio de dos inocentes, víctimas de la ligereza y debilidad de un rey que "era hombre muy credulo, y que sse rregia por priuados sin ninguna orden [...] era muy mudable"'55. La arquitectura del conjunto se resuelve en una apología con corolarios de confirmaciones de bienes y privilegios; y bien lograda además, en su perfil general. Pero conviene pasar a los detalles.

Veamos primero lo que "suena" a auténtico del doctor Galíndez, o por lo menos a bien imitado. La cita de Juan de Mena, por ejemplo. Cualquier español culto podía conocer el poema del cordobés; pero Galíndez parece tener una predilección especial por Mena: "Juan de Mena, nuestro Poeta castellano, asaz conocido a todos por fama', escribe en la Prefacion en la Crónica del Rey don Juan el Segundo, mientras en las Adiciones genealógicas anota: " $\mathrm{D}$. Lorenzo de Avalos, camarero mayor del Infante D. Enrique, de cuya muerte hace mencion Juan de Mena en sus Trescientas" 56. También el recuerdo del Romance no desdice de la cultura y de cierto género de información que a veces Galíndez exhibe. Notaba justamente Floranes que "el señor Galíndez en cuanto escribía, manifestaba luego no sé qué gusto de curiosidad genial para notar cosas curiosas y gratas pasadas por otros en silencio',57. Y en efecto los numerosos y tupidos escritos de Galíndez merecerían una exploración en busca de "folklore" de todo tipo. Dentro de lo poquísimo que he escudriñado, encuentro otra cita de romance en un párrafo sobre Bernardo del Carpio: cuando los enfrentamientos entre el héroe y Carlomagno -escribe-, "se levantó aquel romance antiguo allí donde dice: "do perdio Carlos la honra: murieron los doze Pares"" 58 . El romance al cual pertenecen tales versos es el que empieza "Mala la hubistes, franceses, / la caza de Roncesvalles', que nada tiene a que ver con Bernardo; o Galíndez conocía de él sólo los dos versos que cita, muy corrientes, o bien quería arteramente rendir un ingenuo home-

${ }^{55}$ GenRM, pp. 669.

56 "Prefacion", en Crónicas de los Reyes de España, BAE, t. 68, 1953, p. 273; Adiciones, p. 448.

${ }^{57}$ R. Floranes, op. cit., p. 379.

${ }^{58}$ Adiciones, p. 520. En esta recopilación encuentro otros sucesos y personajes que llegaron al Romancero, pero sin citas de los romances: la ejecución del duque de Guimaraes (p. 429), el asesinato de la duquesa Braganza (p. 430) y Juan Lorenzo de Acuña, "el de los cuernos dorados" (p. 506). 
naje al que indica como progenitor de su propia estirpe. Está claro que un buen romance viejo podía ser alhaja muy anhelada con que adornar alcurnias, como no solamente el doctor Galíndez muestra saber. Él había trazado, de su propia alcurnia, nada menos que este recorrido: Bernardo del Carpio casó con doña Galinda, hija del "conde de Alarcos"; de ambos nació Galín Galíndez y derivó un linaje en parte relacionado con los soberanos aragoneses, "como parece por una genealogía antigua en latin que yo tengo y por otras antigüedades dondesto se prueba"'; hay más: "yo tengo una escritura de un quinto ó un sesto abuelo mio deste linaje que era de Caceres" que revela cómo sangre de los Galíndez se mezcla con sangre de Ayala, notoriamente "levadura de linajes" ("e yo lo oi al Rey Catolico que descendia de ellos"). El juego está hecho: de Bernardo del Carpio al doctor Galíndez, rozando los Ayala y el rey Católico ${ }^{59}$.

Constatamos que también nuestro Galíndez padece el mal del siglo, ese ardor de alcurnia que es casi delirio, vistos los contenidos de que se complace. Entonces, si en un escrito auténtico suyo se aproxima a Fernando, pudo muy bien aproximarse a Isabel en otro escrito que se le atribuye. En efecto, el pasaje sobre la reina Católica y el Romance en la $\operatorname{Gen} B$ se presenta así:

La historia tragica de este hecho lamentable anda en un rromançe antiguo que solia oyr cantar muchas veces la reyna catolica, enterneciendose del agravio manifiesto que hizo don Fernando a estos cavalleros y con admiraçion del justo castigo con que Dios manifesto el testimonio que dio de la verdad que dijeron poniendo al señor por testigo que estavan ynocentes de los delitos de que los acusavan; y no es marauilla que se enterneciese porque como dicen la sangre sin lumbre hierve y ella viene por linea derecha de un hijo de un primo hermano destos caballeros, como en su lugar se dirá60.

Si un día vuelve a aparecer el ms. toledano, tomaremos visión de esa "línea derecha". Pero es suficiente el fragmento que por

${ }^{59}$ Adiciones, pp. 520-521, 523 y 536. Para la p. 523 un anotador avisa al margen que Galíndez muestra no conocer bien el linaje de Ayala.

${ }^{60}$ V. Barrantes, op. cit., p. 47 y M. Menéndez Pelayo, Antología, t. 7, p. 25 y n. Don Marcelino no deja pasar sin censura lo del parentesco entre Carvajales y la reina Isabel; pero en tal materia todo puede ser: ARGOTE DE Molina en su Nobleza, I, $2^{\circ}$, cap. 89 , p. $216 \mathrm{v}$ demuestra, con una retahila de primos y sobrinos y matrimonios, exactamente esa ascendencia de la reina Católica. En nuestro seudo-Galíndez, más que la autenticidad del dato cuenta el contexto de exaltación de la estirpe. 
ahora tenemos para hacernos una buena idea de su prosa limpia y bien construida, como demuestra el segmento que acabo de transcribir; una prosa radicalmente distinta respecto a la de GenRM. ¿Cuál es la de Galíndez, si de él es el "memorial” genealógico?

Volvamos al trozo de GenRM copiado antes. Las versiones sobre antecedentes y causas de la condena y modos de la ejecución se alegan y discuten con equilibrio; el proceder disquisitivo suena a típico de muchas páginas auténticas del doctor Galíndez. Se capta cierta prudencia y cierto humor positivista de erudito ante la problemática autenticidad del emplazamiento y su efecto en la muerte del rey. Menudean expresiones como "segun diçe", "se cuenta", "otros dicen", "dicen algunos", "se cree", que autorizan una información pero sobre todo subrayan el papel de recolector de testimonios de quien escribe. Casi todo está rodeado de dudas. La muerte de los dos hermanos: ¿degollados, como dice la Crónica (?), o despeñados, como dice el Romance, o antes degollados y después despeñados? La muerte del rey: "puso admiracion", es cierto, pero "si ello fue por aquello o por otra causa solo dios lo saue'". La culpa eventual de los dos hermanos: fechorías en el reino, según dice el Romance, que afirma la inocencia; en realidad parece que hay que remontar a un reto: ¿entre un Carvajal y un Benavides?, ¿ entre dos Carvajal y dos Benavides?, ¿Burón de Benavides o Burón es linaje distinto? ¿o con los Coviles? Se perfila la eventualidad de otro reto: una noche en Palencia saliendo... y resuena aquí la voz de la Crónica fernandina.

Pero GenRM nos guarda otra sorpresa dos páginas más adelante, cuando nos depara una nueva versión de todo el episodio; y esta vez en una prosa muy suelta, sin tropiezos ni pausas de dudas. El Carvajal "muy seruidor, y priuado del Rey Don Sancho" es ahora un tal Pedro, que al morir el rey puso en el escudo familiar una banda negra en señal de luto:

y este Don Pedro de Caruajal des que muerto el Rey Don Sancho, que ouo por hijo al Rey Don Fernando quarto en tiempo de su tutela del dicho Rey Don Fernando ouo Çierta question y trançe, que se llamaua Don Pedro Buron, que deçian queran de los Venauides, el qual desafio se hiço en Valladolid a la puerta del campo, que por aquello ouo aquel rrenombre, y alli ouieron su trançe el Don Pedro de Caruajal con el de Venauides e de Buron e mato el de Caruajal a el de Venauides, del qual Don Pedro de Buron quedo un hijo que se crio con el Rey Don Fernando, que después fue su camarero, y gram priuado, y a esta causa el de Caruajal fue a granada donde estuuo algunos años hasta que el Rey Don Fernando fue hombre, 
y paso al andaluçia a uisitalla, y sauiendo como Don Pedro de $\mathrm{Ca}$ ruajal estaua en granada mando llamar a Alonso de Caruajal que era su hermano maior, y Dixole que debajo de su seguro imbiase por su hermano Don Pedro, el Don Alonso imbio y el Don Pedro visto el siguro del Rey vino alli adonde estaua, y como aquel camarero suio era priuado lo hiço prender, y a causa que Don Alonso de Caruajal se quejaua de la prision de su hermano le prendio el Rey tambien, y mando tomalle algunas fnerças, que tenia, y porque no las queria entregar los mando degollar a entrambos hermanos, y diçen algumos que este achaque tomo tambien el Rey por la otra muerte de Joan Alonso de Venauides, que auia acaeçido en Palençia como es dicho, y deçia el comendador trejo el Viejo, que era hombre leido quel de Buron, cuio padre mato Don Pedro de Caruajal, los hiço degollar, y murio el Rey Don Fernando enPlaçado, y le hallaron en la cama muerto, a cuia causa fueron en casa de Alonso de Caruajal, y la derrocaron, y mataron çiertos hombres en ella, y vn criado suio tomo un hijo que alli estaua del Don Alonso de Caruajal, que se llamaua Don Sancho, a quien despues llamaron Don Sancho de Caruajal el gordo, y vna hermana deste, que se llamaua Doña Leonor, con los quales que eran niños huio en Francia $[\ldots]^{61}$.

A continuación se cuenta que Alfonso XI, informado por un fraile, hizo volver a los hijos de don Alonso y los casó muy bien, restituyéndoles sus bienes acrecentados con extensos territorios, detalladamente nombrados. Se concluye con la exposición de la descendencia directa de Sancho de Carvajal hasta llegar al "abuelo del Doctor Caruajal"' y con la consideración que "estas rrelaçiones aunque son diferentes no son asi contrarias, que no se puedan en algo compadeçer, pero lo que primero se dixo paresçe por escripturas antiguas" 62 .

${ }^{61}$ GenRM, pp. 672-673 y ff. [7r-7v] del ms. Nótese el aspecto de burdo agregado que tiene la frase "que se llamaua Don Pedro Buron [...]" y cómo más adelante vuelve "Joan Alonso de Venauides". En el 'Memorial de la calidad, y servicios de la Casa de Don Álvaro Francisco de Villoa Golfin y Chaves, Madrid, 1675, f. 25v, don Sancho el Gordo resulta ser el padre de los hermanos ajusticiados, a los cuales no se atribuyen herederos: "Y aunque Algunos sean de Otro Sentir, lo que Escrivimos consta por Instrumentos". En f. 17r cita con gran aplauso "las memorias Genealogicas que dexó escritas de los Carvajales el Doctor Lorenço Gonçalez [sic] de Carvajal"'; pero en la parte que nos interesa le contradice implícitamente tres veces: Sancho el Gordo como padre de los despeñados y no hijo de uno de ellos, los nombres de los despeñados (Juan Alfonso y Pedro Alfonso) y la negación de descendientes de los hermanos. ¿Conocía otro texto más de la Genealogía?

${ }^{62}$ GenRM, p. 674. 
Estas últimas frases confirman lo que trasluce del conjunto de páginas -extenso en demasía- dedicadas al argumento: un proceder por acumulación de documentos y tradiciones, un intento de compaginar datos contrastantes y el objetivo típico de quien redacta o relabora tales escritos, que es arrimar agua al propio molino. Lo de la descendencia de los dos hermanos es sintomático, por primordial en los intereses del autor o más bien de los autores: "eran deudos muy çercanos de los de Plasençia porque los de Plasençia venían dellos", y a los de Plasencia se conectaba Galíndez; pero pocos renglones después leemos: "no fueron destos [de Plasencia] los despeñados, porque aquellos tenian su asiento en Valençia [...] y estos de que hablamos viuian ya en Plasençia al tiempo que aquello aconteçio" 63 . Con su lenguaje suelto y tajante $G e n B$ asienta que aquel Sancho, hijo de uno de los hermanos, "tuvo muchos hijos y hijas de quien vienen los carvajales de caceres y trujillo"64. Era natural que para tantos Carvajales fuera indispensable en Sancho prolífico, de quien GenRM nombraba sólo dos hijos, siendo una además hembra. Sin embargo, GenB encabezaba su párrafo con la autoridad del propio Galíndez: "Dice tambien el doctor Galindez de carvajal que reynando el rey don alonso el onceno un su confesor [...]", y sigue lo que ya sabemos sobre las mercedes, pero con un suplemento importante: ese rey fue tan generoso hacia los Carvajales "tambien por el deudo que con ellos tenia", agregándose así el vencedor del Salado a los otros dos parientes coronados, Fernando e Isabel. El remite a Galíndez muestra a las claras que $\operatorname{Gen} B$ ha sido redactada por otra mano, la mano de alguien que en ese documento concentró tiempo para seleccionar y ordenar y exponer bien los datos, y concentró sobre todo una ambición de mayor alcance, para la cual el episodio de los dos hermanos contaba por sus resonancias y su posteridad más que en sí mismo. Emblematizado en la banda negra (a la cual $G e n B$ dedica cierto espacio ${ }^{65}$ ), el episodio vale por lo que ha suscitado: las reparaciones alfonsinas y las lágrimas de la reina Católica.

${ }^{63}$ Ibid., pp. 669-670.

${ }^{64} \mathrm{~V}$. BARRANTES, op. cit., p. 48.

65 " $[. .$.$] porque no se perdiese la memoria de tan injusto suceso es co-$ mun tradicion desta ciudad que la vanda de sus armas que solia ser açul la volvieron en negra, y esto asi se platica en esta çiudad y he oydo a personas ançianas della que vieron esta vanda açul en cierta chimenea antigua que al presente está renovada en la casa del Sr. tesorero de plaçençia don diego de 
El texto de GenRM conoce las dádivas de Alfonso y deja constancia de la conmoción de Isabel, pero en un contexto donde resabios de un afán disquisitivo y de un gusto historiográfico no contribuyen a dar el debido realce simbólico a ambos hechos, aunque el conjunto resulte marcadamente celebrativo. Este texto no conoce la simplificación orientada que preside al otro. Pero, más allá de la apología genérica, también GenRM quiere proporcionar una lectura de los datos que los armonice con la exaltación del episodio, finalidad esta muy desdibujada en $G e n B$ pero bien presente en $G e n R M$, donde casa perfectamente con una actitud de su autor que es más de comentarista analítico que de sintetizador. Un ejemplo muy oportuno nos viene del pasaje sobre el Romance.

La existencia del Romance era en sí un elemento muy significativo y por lo tanto era obvio que su texto se transcribiera y dilucidara, sobre todo ya que afirmaba la inocencia de los dos hermanos e iba acompañado del prestigio de una cita de Mena y de un interés de la reina Isabel. Pero el texto mismo y cada uno de estos datos requerían una exégesis. El texto, en primer lugar. Contiene una parte de información dudosa o equivocada, frente a la

carvajal", V. BARrantes, op. cit., p. 48. Lo de la banda de luto es tema intrincado también y con sus distintas versiones, según la idea que en ella se quiere simbolizar: GenRM, cuyo tema de fondo es la constante lealtad de los Carvajales a los reyes, motiva el paso de azul a negro con la muerte de Sancho IV, aunque informa que en opinión de otros la banda fue siempre negra; $G e n B$, que se guía por la exaltación del sacrificio de una familia, refiere la versión consiguiente y para borrar dudas se ampara en la tradición local, citando incluso testigos oculares (!) de cuando la banda era azul.En su Blason y recogimiento de armas (¿1495-1506?), GARCía Alonso de TORRes escribe: "dicen algunos que primero la vanda era açul y que quando los dos hermanos Carbaxales vençieron el campo contra otros dos hermanos del linaje que dicen de Urones, y esto se fue en la villa de Valladolid ala puerta del campo; y por que el uno de los Carbaxales fue vencedor del Rey le mando cortar la cabeça, y por luto pusieron la vanda negra. Otros dicen que la pusieron negra por dos deeste linaje que fueron despeñados dela peña de Martos"' (f. 149v del ms. C-45, fondo Salazar de la Biblioteca de la Real Academia de la Historia de Madrid, probablemente copia del original: cf. Índice de la Colección de don Luis Salazar de Castro, t. 12, Madrid, 1955, p. 41, donde se informa que Torres era "cronista y rey de armas de Fernando el Católico en 1474", y R. Floranes, op. cit., p. 404). Los pocos renglones de G. Alonso de Torres aparentan presentar un par de novedades que me limito a señalar: la decapitación de un Carvajal y la distinción entre los dos hermanos del duelo de Valladolid y los dos hermanos despeñados en Martos. ¿'Ignorancia y confusión de Torres, sorprendente en un cronista, rey de armas y tratadista de heráldica, o bien síntoma de muy variadas tradiciones alrededor de los dos míticos hermanos ajusticiados? 
cual conviene colocar lo que resulta de fuentes más canónicas ${ }^{66}$; el amparo de Mena y de Isabel autoriza el espacio que se abre al Romance y ese cotejo, al mismo tiempo que sustrae a la sospecha de una predilección subjetiva del recopilador el injerto de un canto marcadamente celebrativo de sus dos antepasados: el poeta nacional y la reina de todas las Españas a la vez que dan autoridad al texto despersonalizan su cita. Ambos atestiguan también la amplia difusión, en el tiempo y en el espacio — social—, de un texto tan provechoso para el clan de los Carvajal. Pero aquí debe intervenir otra aclaración. Juan de Mena "dixo rrustico cantando", con una aparente limitación implícita de la circulación del canto en ambientes que hoy diríamos de cultura subalterna; implícita podía aparecer también una devaluación del texto cantado, patrimonio - ¿y fruto? - de gente inculta y aficionada a patrañas. El autor de GenRM tiene preparada una doble maniobra. Con "rrustico" — nos dice- Juan de Mena define el segmento final, el de las "aldeas", de una trayectoria de difusión que pasó antes "por todos los de los Reynos largos tiempos", que es como decir -en oposición a "aldeas" - ambientes de la cultura oficial y de la ciudad: Galíndez (o quien sea) nos da un curioso precedente de la moderna teoría del folklore poético como material culto descendido al pueblo. Y para desmentir del todo una interpretación demasiado literal de la indicación de Mena ¿qué mejor alegato que el aprecio del Romance por parte del vértice de "todos los de los Reynos", la reina Católica Isabel? La "atençion" con que lo oía, que parece matizarse de una íntima afectuosidad, es además el sello ulterior y más carismático sobre el vínculo que ha vuelto a anudar a los monarcas con los Carvajal desde Alfonso $\mathrm{XI}$, reivindicando una antigua e incontaminada lealtad.

¿Quién fue el testigo directo del interés de la reina Isabel hacia el Romance? No fue quien sobre ello escribe en $G e n R M$, porque para tal noticia remite a una fuente no indicada: "et qui videt" y el espacio en blanco no dejan lugar a dudas. Si la autoría de ese pasaje se quiere atribuir al doctor Galíndez, no fue él el testigo aludido; y si el testigo fue él, por lo menos ese pasaje de GenRM no le pertenece. Esquematizar así sobre cuestión, papeles

66 También GenB hace su crítica, fundada en el principio que "estos rromançes antiguos suelen y deuen tener mucha autoridad en lo que no contradicen á historias, como este, que dice que el rrey confesó y comulgo con la enfermedad y que le vieron morir, porque lo uno y lo otro es falso como consta de las coronicas allegadas", V. BARRANTEs, op. cit., p. 47. 
y temas tan enrevesados quizás pueda parecer excesivo, aunque la claridad de ese punto del texto creo que lo impone. Creo también que no hay materia para ulteriores especulaciones. Pasemos, por lo tanto, al Romance, cuyos textos doy en el Apéndice.

Las fuentes hasta el momento conocidas nos dan esencialmente dos versiones del Romance, cada una con dos variedades. La versión atestiguada en transcripciones de fecha más temprana es la contenida en $\operatorname{Gen} R M(=G)$, con toda la problematicidad de este testimonio, y -en texto más corto y con notables variantes- en un pliego suelto de la Biblioteca Universitaria de Cambridge $(=\mathrm{Ca}$ ). La otra versión se documenta más tardíamente y es la impresa en dos pliegos sueltos, uno en Praga $(=P)$ y otro en Madrid ( $=\mathrm{MN}$ ), y - con variantes- en el Cancionero de Romances $(=C R)$ y en la Silva $(=1 S 50 Z)$.

La diferencia básica entre las dos versiones estriba en que una presenta la querella contra los Carvajal en discurso indirecto y la otra en directo. Por una especie de paralelismo, tan curioso como casual, el texto $C a$ de la primera versión exhibe una contaminación en su final, mientras ofrece una contaminación distinta, y en su comienzo, la versión más tardía ${ }^{67}$, en sus dos variedades, siendo éste otro vistoso elemento distintivo suyo, que merece un breve comentario. Menéndez Pidal juzgó esos primeros veinte versos, con asonante propio -éa, como pertenecientes a algún romance perdido sobre Fernando III el Santo, "de quien, según opinión tradicional, procede la costumbre de servir nuestros reyes la comida a los pobres el Jueves de la Cena', y a quien los actos de fervorosa religiosidad exaltados en los versos se convenían mucho mejor que al IV de los Fernando; la homonimia sería responsable de la contaminación, afortunada por conservarnos casi ciertamente la reliquia de un canto que pudo ser del siglo $\mathrm{xIII}^{68}$. Ocurre que el contenido de ese probable agregado encaja muy bien con la lección de nuestro Romance, cuyo relato es tradicionalmente un exemplum de "caída de príncipes" de gran eficacia. Esa eficacia, en efecto, encuentra un refuerzo notable en el caer la condena de Dios sobre la cabeza de un monarca que en el exordio del texto es espejo de heroica y humilde devoción. La contamina-

${ }^{67}$ Entiéndase "primera versión", "versión más tardía” y expresiones similares referidas a las fechas de sus testimonios impresos o mss.

${ }^{68}$ R. MenÉndez Pidal, Romancero hispánico, t. 1, pp. 311-312. 
ción pudo ser muy bien textual, pero no descartemos la eventualidad de que pudo darse entre temas y motivos tradicionales, reuniéndose en el Fernando Emplazado atributos del Santo, que en parte eran propios ya de los soberanos de Castilla, como la distribución de la comida a los pobres. Apoyaría la hipótesis de un cruce entre textos la distinta asonancia, elemento importante desde luego aunque no determinante, por no ser raros los romances seguramente unitarios con pluralidad de asonancias, rasgo que se suele considerar como señal de antigüedad. Hueca de sentido es, al contrario, la contaminación de que adolece $C a$, determinada exclusivamente por la homonimia y la identidad de situación, y que se extiende con el automatismo típico de tales remiendos casuales, pero preservándonos así una versión del romance que empieza "Doliente estaba, doliente" con algunas variantes respecto a los textos corrientes. Una huella mínima y apropiada de esta contaminación la encontramos en $P$ : son los versos "el cuerpo cara oriente/ y la candela en la mano", versos y motivo formulísticos que pudieron pertenecer autónomamente a una versión de nuestro $R o^{-}$ mance y haber estimulado el cruce ya comentado 69 .

$\mathrm{Al}$ entrar en el que tendríamos que considerar el exordio auténtico del Romance - y tal es sin más en $G$ y en $C a$-, se nos vuelve a plantear el problema de la posible contaminación con el hipótetico romance sobre Fernando el Santo. Esa "pascua" y ese "cabodaño", que en $P$ casan muy bien con la ambientación creada por el "falso" exordio, sorprende encontrarlos también en $G$ y en $C a$ que desconocen el "falso" exordio. Esta presencia unánime ( $C R$ varía en propio $)^{70}$ sorprende también, porque no hay huella de tales fiestas ni en las Crónicas ni en Almela ni en García de Salazar; tenemos que juzgarlas un rasgo privativo del Romance, por lo menos según los textos que conocemos, rasgo totalmente novelesco y muy curioso. En efecto, si $G$ y $C a$ atestiguan el exordio puro y auténtico, es inevitable preguntarse el porqué de esa evocación de "pascua" y "cabodaño" así a secas; la pregunta no surge frente a $P$, con su exordio impuro pero esclarecedor de la cita de las dos fiestas. Es evidente que los lazos con la posible con-

${ }^{69}$ Cf. también F. J. Norton y E. M. WiLson, Spanish verse chapbooks, Cambridge, 1969, pp. 49-50, donde se apunta que para el Romance de la muerte de Fernando I, "Doliente estaba, doliente", gracias a la contaminación, el pliego de Cambridge (véase Apéndice para la fecha) plantea al Cancionero de romances como más antiguo testimonio. Toda esta parte del libro citado se debe a Wilson.

${ }^{70}$ Elimina "pascua" y "cabo de año", cf. Apéndice. 
taminación se presentan más intrincados de lo que podía parecer a primera vista, y quizás tengamos que suponer más bien antigua la situación textual con el "falso" exordio y considerar los comienzos de $G$ y de $C a$ resultado de un corte, amparado por un incipit formulístico insospechable pero desenmascarado por los versos 3-4. De ese corte, si se dio, no haría responsables a sus dos testimonios actuales.

En esta zona de abertura del Romance nos impone otra demora también la geografía. En las Crónicas el rey sale de Jaén y llega a Martos, teatro de nuestro episodio; de allí acude al sitio de Alcaudete, donde enferma; regresa a Jaén y muere. Los textos del Romance se distinguen de las Crónicas y al mismo tiempo difieren entre sí. Aparte la contaminación, $\boldsymbol{P}$ se abre en Jaén con la pascua, pasa a Martos con el cabo de año, coloca en Alcaudete la querella contra los hermanos, en Medina del Campo su captura, en Jaén la sentencia del rey y en Martos el despeñamiento; la muerte de Fernando se supone que acontece en Jaén. Itinerario idéntico en $C R$, con dos variantes: desaparece el Martos del comienzo y el rey muere nada menos que en León ${ }^{71}$. Respecto a $\boldsymbol{P}$, en $C a$ parece ser Alcaudete el lugar donde se concentran la querella, la condena y hasta la muerte del rey; la Peña de Martos o la Sierra de Aillón serán el teatro de la ejecución. La misma alternativa ofrece $G$, que parece coicidir con $C a$ en privilegiar Alcaudete, aunque de una manera menos clara: la rotunda indicación de su primer verso, en efecto, queda ofuscada por la referencia a Martos en el verso 4, referencia que tendría que remitir al pasado, haciendo como hace pareja con la indicación del verso 3 a Jaén; una vez más "pascua" y "cabo de año" entorpecen la marcha del exordio. Pero tampoco en los demás textos la información sobre el papel de Alcaudete resulta clara, porque hay que deducirla de un detalle: el rey recibe la querella contra los dos hermanos cuando está todavía con los pies en los estribos y no ha "descavalgado", o sea nada más llegar a Alcaudete. El hilo de tal indicación es tan sutil - pero ineludible - que bastaría haber encontrado en vez de "no havia descavalgado" una lección como "no hauia caualgado" para eliminar Alcaudete y sustituirla con Martos. Es la lección que presenta $1 S 50 Z$, de manera que en su texto la primera parte de nuestro episodio se desarrolla en Martos. No creo que se trate de una variante casual. Era inevita-

${ }^{71}$ F. J. NoRton y E. M. Wilson, op. cit., p. 50; se ve en esto una superposición del relato sobre Fernando I. 
ble que en la tradición del episodio la localidad teatro de la muerte injusta de los dos hermanos acabara predominando sobre las demás, dado el escaso relieve novelesco y dramático que podía tener el vaivén histórico de Fernando; vaivén del que parece quedar huella, sin embargo, en el Romance en ese motivo de los desplazamientos con ocasión de las fiestas. El relato de Almela ya concentra los sucesos entre Martos y Jaén, donde el rey muere antes de emprender viaje a Alcaudete. En García de Salazar se llega al extremo de reunir todo en la misma Peña de Martos, única localidad nombrada. Bien es verdad que la concentración en el Valerio favorecía el didascalismo efectista y en las Bienandanzas la eficacia de la anécdota maravillosa; por lo tanto podríamos pensar en una intervención de los respectivos autores. Pero conviene recordar el incipit de nuestro Romance que cita en su Crónica Francesillo de Zúñiga: "En Martos está el buen rey"72. Es muy probable que la continuación de ese texto no difiriera mucho de los conocidos y que ese incipit fuera nada más que el síntoma del valor emblemático de Martos, que se sobreponía a otras localidades en la memoria del mismo Zúñiga o de algunos transmisores; pero no descartemos la eventualidad de que el lugar fatídico haya podido orientar una versión entera del Romance, como quizás sugiera la página de García de Salazar.

La querella ante el rey en contra de los dos hermanos ya del verso 5 al 10 en $G$, del verso 9 al 16 en $C a$, del verso 27 al 42 en $P$, y del verso 27 al 44 en $C R$. El aumento progresivo del número de versos - de seis a dieciocho- conforme avanza la cronología aparente de los testimonios, podría llevarnos a suponer amplificaciones sucesivas de un motivo, fenómeno bien conocido en poesía tradicional. Pero la regularidad de ese incremento paralelo de versos y de fechas parece demasiado perfecta para ser

${ }^{72}$ Cuenta don Francesillo que Gutierre de Cárdenas, yendo en camino de Granada a Ocaña con el Emperador, silencioso y malhumorado por el coste de sus infructuosas peticiones de un cargo, acercándosele Carlos V ya en proximidad de Martos, le dijo de pronto: 'Señor, Vuestra Majestad debía de procurar saber el romance que dicen "en Martos está el buen rey" y aquí murieron despeñados los Carvajales". El Emperador apreció la alusión y concedió a don Gutierre el oficio que pedía; cf. Crónica burlesca del Emperador Carlos V, ed. D. Pamp de Avalle-Arce, Crítica, Barcelona, 1981, p. 152. El Romance ha sido evocado como ejemplo, y escarmiento, de monarcas injustamente crueles con los hidalgos. "Martos" podría haber sido una adaptación del momento. 
del todo creíble, en un ámbito de documentación regido por la casualidad y donde es principio sano postular una discrepancia entre fecha de la fuente y época del texto, mientras falte la prueba en contra. Por lo tanto conviene observar la situación de este segmento más que desde la perspectiva de una dudosa diacronía, desde la de su tipología y organización.

$\mathrm{El}$ incremento atañe en particular a los varios desafueros achacados a los Carvajal, que en su versión más desarrollada - la de $P$ - encontramos también en el Romance del duque de Arjona. Se trata, al parecer, de una serie de lugares comunes extraños a la fábula o a la historia originarias que respaldaban los asuntos de ambos romances $^{73}$; pero lugares comunes que todavía en los siglos XIV y $\mathrm{xv}$ reflejaban situaciones reales por la supervivencia de una arcaica y aventurera actividad de rapiña protagonizada por individuos de la nobleza, a veces en el contexto de luchas civiles y enfrentamientos de bandos. En $P$ y en $C R$, que acogen la versión más amplia, los villanos vejados aparecen en primera persona. Puede que esta coincidencia no sea casual. La salida a la escena de los villanos acusadores como interlocutores directos del soberano incluye la forma dialogada en una zona del texto donde $G$ y $C a$ presentan pocos versos de relato indirecto como preámbulo a la captura de los hidalgos, al emplazamiento del rey y al martirio de los dos hermanos: son éstos los puntos focales de la versión de $G$ y $C a$. Aunque no sea más que ante los fueros de la técnica narrativa, el diálogo directo entre los dos extremos de la sociedad, los villanos y el rey, es una dignificación objetiva de quienes se proclaman víctimas en la primera parte del Romance. Se define además "vasallos" del monarca; y el detalle podría llevarnos a sospechar en el texto la sugerencia de una condición jurídica de labradores de tierras de realengo y no de dominio señorial o - si recogemos la alusión del rey a los ganados- de una condición de pastores pecheros directos de la corona ${ }^{74}$. Se perfila así una

${ }^{73}$ M. Menéndez Pelayo, op. cit., t. 7, pp. 76-80 y R. Menéndez Pidal, Romancero hispánico, t. 1, p. 311, y t. 2, p. 8.

${ }^{74}$ No entro en una temática jurídico-social que me es extraña y que se vislumbra detrás del aparente esquematismo y formulismo de temas y versos romancísticos. Me limito a dar unas indicaciones bibliográficas: M. DEL C. CARLÉ, "Infanzones e hidalgos" ", Cuadernos de Historia de España, 1961, núms. 33/34, pp. 56-100, especialmente pp. 89-94; M. A. LADERo QueSADA, El siglo XV en Castilla. Fuentes de renta y politica fiscal, Barcelona, 1982, passim y en esp. p. 38; y J. VALDEÓN BARUQUE, Los conflictos sociales en el reino de Castilla en los siglos XIV y XV, Madrid, 1975. 
primera parte del Romance (casi la mitad del texto en $P$ y en $C R$ ) que retrata la figura unitaria de un soberano devoto y piadoso con los afligidos, paterno y justiciero con los débiles. Es el resultado de un enfoque narrativo brotado del posible resquebrajarse del monolitismo ideológico que exhibe el Romance en su versión documentada más tempranamente, la de $G$ y $C a$. Pero el juicio divino delatará como falsas las acusaciones de los villanos; por lo tanto, su desarrollo y el del marco que las realza deberíamos leerlos como un artificio para exaltar el mentís ultraterreno a unos vulgares calumniadores y la sufrida inocencia de los dos hidalgos. Así y todo, el espacio y la articulación que ha adquirido este motivo, tan sólo preliminar en otra rama de la tradición, hacen tambalear el firme eje proseñorial que sin duda sostiene el Romance. Me parece innegable que la dramatización de la queja de los villanos no agota su función sólo en los efectos poéticos, apoyados en el estilo formulístico e iterativo y en las antítesis: $c f$. los versos $27-30,31$ y 41 . La amplitud y la construcción del segmento, al realzar en $P$ y $C R$ la fugaz querella de $G$ y $C a$, dan a su contenido un marcado matiz conflictivo, ausente o muy débil en la otra versión. Veremos más adelante otro aspecto de reorientación de perspectiva en $P$ y $C R$.

Protagonistas de las secuencias sucesivas son ya los dos hidalgos frente a la autoridad del monarca. Dimensiones y modos de su protagonismo varían significativamente en los distintos textos del Romance. Dejando aparte $C a$, portador de un texto de indudables rasgos arcaicos pero maltratado por la tradición, y no considerando la parte fina' de $C R$, con un segmento tan exhaustivo como prosaico y que sabe a remedo ${ }^{75}$, quedan enfrentados $G$ y $P$. Si el primero no contempla un encuentro de los hidalgos con el rey, el segundo encierra en dos octosílabos formulísticos un saludo de los presos y la airada contestación del soberano. En cambio, es la queja de los hermanos, por boca de uno de ellos ${ }^{76}$, la que gana espacio en $G$ y va encaminada a exaltar la lealtad de los hidalgos para con el rey: han sido vasallos fieles que nunca

75 Pero cf. en el texto de Lope García de Salazar: el rey "no se curo de1lo" y el v. 83 de $C R$. A Wilson (véase Norton y Wilson, op. cit., p. 50) este final de $C R$ le parece más emparentado con el de $C a$ que el texto de $P$; pero recuerda el vínculo de los vv. 41-42 de $C a$ con $P$, sin duda más relevante.

${ }^{76} \mathrm{El}$ "'menor" en $C a, P$ y $C R$ contra el "mayor" de la tradición que llegaba de García de Salazar, todavía no folklorizada en ese detalle; una folklorización ulterior representa el v. 72 de $P(=C R)$ respecto al v. 26 de $C a$. 
han atentado contra la integridad patrimonial de la corona y siempre han garantizado protección a la persona del soberano. No se toca el motivo del imperfecto proceder judicial, como ocurre en $P$ y en la tradición de la queja según Almela, García de Salazar y los comentarios de GenRM. La protesta se centra sobre la información del respeto de los vínculos fundamentales que unen el vasallo al rey, y acaba sosteniendo implícitamente que tan sólo una falta relacionada con esos vínculos podía motivar la ira del soberano; queda excluida cualquier otra materia como extraña a la relación - y a la censura- jurídica entre los hidalgos y el rey. Es inevitable sacar de $P$ y de $C R$ la consecuencia que los hidalgos son inocentes tan sólo porque la información de los villanos ha resultado falsa, y que el rey es culpable por no haberles permitido la demostración de esa falsedad, o sea -es implícito- por haber concedido más crédito a los acusadores que a los acusados, en sustancia por un proceso judicial anómalo, o mejor dicho omitido del todo: cf. los versos 74 y 83 de $P$ y el verso 85 de $C R$. Igualmente inevitable es constatar que en $G$ la pena de los hidalgos es inmerecida e injusta sólo porque nunca hicieron "desaguisado" contra los bienes y la persona del rey, según los términos ya comentados. Con una imagen fácil, y quizá simplista y excesiva al mismo tiempo, podríamos decir que en las dos versiones se reflejan dos épocas y dos mundos; pero sería simplista la imagen porque esos dos mundos convivían en la misma época, y sería excesiva porque en poesía tradicional (¿`sólo?) siempre está al acecho para corroer nuestras arquitecturas el gusano de la sospecha: el gran edificador pudo ser nada más que el azar.

El tema de la lealtad en $G$ tiene una acentuación especial: cf. los versos 21-22 (= P 61-62) y los 51-54 con su reiteración de "leales", aunque la identificación de los hermanos Carvajal como dechado de hidalgos altivos y vasallos fieles es propia del Romance en ambas versiones y bien se concentra en el choque con el Almirante $^{77}$, perfectamente glosado en la "amplificación" de $P$ y $C R$.

${ }^{77}$ La presencia de este personaje y la referencia a la feria de Medina del Campo indujeron a Menéndez Pelayo (op. cit., p. 33) a fechar el Romance bien entrado el s. Xv, método que dejaba justamente perplejo a $R$. MEnÉNDEZ PIDAL, Romancero hispánico, t. 1, p. $311 \mathrm{n}$. En el texto de $C a$ desconocido a ambos Menéndez, faltan los dos datos, cosa que se podría achacar a la calidad generalmente mala de este testimonio; pero el segmento implicado no presenta ningún defecto. El "pregón" al cual alude $P$ tiene una curiosa y creo intranscendente analogía con la noticia cronística de la llegada de los hermanos a la corte de Fernando a consecuencia del reto que los convocaba. 
Sin embargo, en $G$ la figura, incluso física, de los dos hermanos promueve aquellos "ensanches" textuales que en cambio $P$ y $C R$ muestran en la primera parte del texto y en favor de los acusadores. Obsérvese la demora en la descripción del tratamiento cruel hacia los hidalgos, a quienes se les saca los ojos además de cortarles pies y manos, aherrojados con "grillos" y "esposas" infames. Son elementos solidarios todos, quizá privativos de $G$ o quizá en él mejor conservados, y pour cause; son elementos que convergen hacia un realce efectista de la lealtad ofendida y de los cuerpos inocentes martirizados, con una orquestación de los rituales que volvemos a encontrar en la solemne composición del tribunal divino, invocado ante la falta del humano, donde el Espíritu del Mal en persona es quien puede sostener la falsa acusación. La grandeza de esta secuencia, que celebra la apoteosis de los dos hermanos, se enturbia o se pierde en los demás textos, todos imperfectos frente a $G^{78}$. Igualmente propia de $G$, y coherente con el proceder pausado y compacto de esta segunda parte del Romance en su texto ${ }^{79}$, es lo implacable - demorado- de la exposición de los últimos cinco días del rey: en uno la enfermedad, en otro la confesión, en el siguiente la comunión, en el sucesivo la extrema unción y en el último y treinteno la muerte ${ }^{80}$. "Roguemos todos a Dios" que le perdone, invoca juglarescamente $G$ a sus oyentes, pero después de haberles proporcionado una muerte de Fernando saboreada gota a gota como terrible espejo del progresivo y final triunfo de los dos hidalgos. ¿Será una casualidad que esta impecable - y no inocente- versión del Romance nos haya llegado dentro de la Genealogía de los Carvajales ${ }^{81}$ ?

${ }^{78}$ Imperfecto era también, o lo ha reproducido mal, el que conocía García de Salazar, que se correspondía con $P$ y $C R$ en presentar a Santiago en lugar de la Virgen en $G$ y en la ausencia del acusador. Esta coincidencia podría atestiguar, más que una imperfección en algunos textos, quizás un exceso de "perfección" en $G$. La movilidad de Santiago nace de la mala lección atestiguada por $P$ : "testimonio" iterado; $C R$ corrige colocando al Apóstol de "escrivano".

${ }^{79}$ La edición sinóptica de los textos en el Apéndice permite una comprobación incluso visual de este aserto; compárese también la primera parte del Romance.

${ }^{80}$ M. Menéndez Pelayo, op. cit., t. 7, p. 28, recuerda que en el relato de las Crónicas la muerte del rey "fue repentina, sin que tuviera tiempo para confesar" (como había observado ya el autor de GenB); así aparece en los otros textos, resultando "la catástrofe más ejemplar y tremenda". Pero gratificadora podía resultar, y en más de un sentido, la morbosa lentitud de la agonía.

${ }^{81}$ Merecen recordarse los meditados renglones que a $G$ dedicó S. G. MoR- 
Frente al final de este texto atesorado en el cofre de la memoria y de los memoriales de una familia, y al calor de ese interesado amparo protegido y quizás redondeado, frente a su bien organizado final de sádica compunción a ojos modernos, resalta más desolada aún la zona conclusiva de $C a$ pasada a través de centenares o miles de memorias anónimas e indiferentes hasta depositar sus ruinas e incrustaciones en un pliego suelto abierto a todos los vientos. Pero puede ocurrir que la indiferencia del común usuario deje sobrevivir en un contexto ya absurdo la huella de una estructura que se hundió. Así ocurre en Ca. Sus versos 31-32 suenan a incoherentes cuando cierran la frase del emplazamiento pronunciada por el menor de los Carvajal, porque no pueden ser contemporáneos de la querella pues aluden al penúltimo día del plazo como ya llegado; esos versos, exclusivos de $\mathrm{Ca}$, deben pertenecer a un momento sucesivo al emplazamiento e incluso a la muerte de los hidalgos. Y entonces, ¿quién los pronuncia y en qué circunstancia? ¿Qué contenía el segmento de texto ciertamente colocado entre los versos 30 y 31 y que la memoria de la fuente de $\mathrm{Ca}$ había perdido? Ese segmento de texto contaba la muerte de los hermanos y agregaba que, a su debido tiempo, "durmjendo [el rey] llamaronlo aquellos dos hermanos en vision", según la frase y el relato de García de Salazar; y llamándolo, debieron de pronunciar un aviso no muy diferente del que se expresa en los versos 31-32 de $\mathrm{Ca}^{82}$. Esos dos versos salidos de boca de los hidalgos ya muertos deben su supervivencia a la anacrónica absorción en la cita gritada cuando los dos hermanos estaban vivos.

LEY, "Chronological list of early Spanish ballao's", $H R, 13$ (1945), pp. 281-282: su texto no le parecía poseer "all the earmarks of a romance antiguo" y respecto al de $C R$ le resultaba "weaker and more like an erudito"; en conclusión, no excluía que pudiera tratarse de una interpolación tardía en un vehículo como la Genealogía, que Morley conocía a través de las citas de Menéndez Pelayo de los extractos de Barrantes $(=\operatorname{Gen} B)$.

${ }^{82}$ Wilson percibió aquí una tradición oral corrompida (NORTON y WILson, op. cit., p. 48), que de todas formas tendía a considerar $C a$ posterior a $P$ y $C R$, basándose en la teoría menendezpidaliana del texto largo como antecedente del más corto. Las páginas que Wilson dedica al Romance son a la par detalladas y descuidadas, y adolecen de falta de información; macroscópica la ignorancia de la contribución fundamental de Menéndez Pelayo, con la consecuencia de desconocer el texto de $G$. Es evidente que la colocación de los vv. 33 ss es perfecta: los vv. 33-34 se refieren a los dos hermanos que hablan al rey en el sueño, tal como sabemos gracias a García de Salazar, ya que mal se avendrían con el discurso de los vv. 27-30, proveniente de un solo hermano (vv. 25-26). 
Pero, ¿los hidalgos del relato recogido por Lope García de Salazar se expresaban en verso, y en verso de romance? Se abren aquí derroteros que una "aproximación" como es ésta no quiere emprender y que prefiero dejar para otro momento o - quizá mejor - para otros investigadores.

Giuseppe di Stefano Università di Pisa 


\section{APÉNDICE}

El Romãce fecho ala muerte de dõ Pedro Caruajal y de dō alōso su hermāo, según el título de su primera ed. conocida, nos ha llegado a través de los siguientes testimonios: $G \quad$ apud Genealogía de los Carvajales, [ms. s. XvII] cit. supra n. 43, pp. 667668; transcribo el texto de las fotocopias del ms., ff. [5v-6r], con mínimas modernizaciones gráficas, mayúsculas y puntuación;

Ca pliego suelto de la Cambridge University Library; ed. facsímil en F. J. NORTON - E. M. WILSON, op. cit. supra n. 69, pp. 78-79; [ ¿Burgos, Fadrique de Basilea, 1515-17 o Alonso de Melgar, 1518-19?]: ibidem, p. 14 ; Dice. n. 990 ( = A. RodríGuez-MoÑino, Diccionario de pliegos sueltos poéticos (siglo xvi), Madrid, 1970);

P. pliego suelto de la Bibl. Universitaria de Praga [s.a.]; ed. facsímil en Pliegos poéticos españoles de la Universidad de Praga, Madrid, 1960, vol. I, pl. XXXIX, pp. 343-344; Dice. n. 710 ;

MN $\quad$ pliego suelto de la Bibl. Nacional de Madrid [s.a.]; ed. facsímil en Pliegos poéticos de la Biblioteca Nacional, Madrid, 1957, vol. III, pl. CXII, pp. 175-176; Dicc. n. 709;

CR Cancionero de romances, Amberes s.a. [¿1547?]; ed. facs. por R. Menéndez Pidal, Madrid, 1945, ff. 165r-166v [156 por equiv.]; eds. sucesivas controladas: Amberes 1550, Amberes, 1568;

$1 S 50 Z$ Primera parte de la Silua de varios romances, Zaragoza, 1550, ff. 88r-89v;

IS50B idem, Barcelona, 1550, ff. 80r-82v [léase 79r-80v];

$1 S 52 B$ idem, Barcelona, 1552, ffr. ut supra.

Un posible perfil de las relaciones entre estos testimonios es el que sigue:

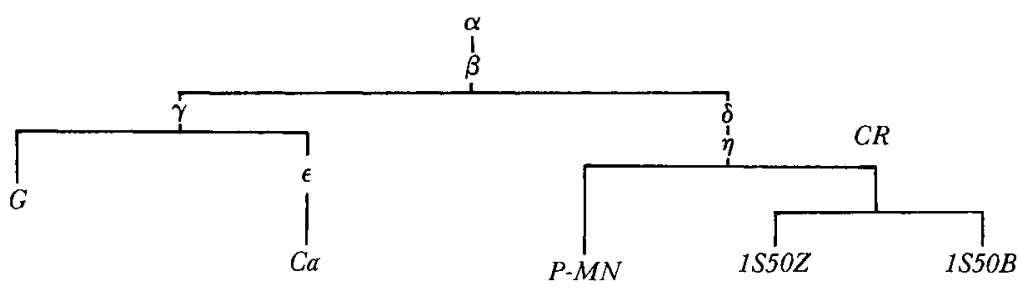

Con $\alpha$ se simboliza el texto que encabeza la tradición conocida y que se supone del tipo representado por $G$ y $C a$. El punto $\beta$ indica el momento de desgaste de la parte final del texto, con la progresiva desaparición del episodio del sueño de Fernando IV. Aquí la tradición se desdobla. Por un lado está 
$\gamma$, sustancialmente fiel a los ascendientes pero con huellas siempre más débiles del sueño, que desaparecerán en $G$ mientras sobrevivirán, mínimas ya, en $C a$; éste pása a través de una fase $\epsilon$, de contaminación con el romance sobre la muerte de Fernando I. En la otra ladera de la transmisión, el texto cobra un perfil distinto con las innovaciones en su estructura y con el injerto del exordio del supuesto romance sobre Fernando el Santo: simplificando y comprimiendo, reúno bajo el símbolo $\delta$ esos momentos, cuando quizás quedaban todavía presencias del sueño pero tan desgastadas que perjudicaron el final del texto. En efecto, el ser distintos los segmentos conclusivos de $P$ y de $C R$, y además claramente remendados, nos hace suponer un antecedente insatisfactorio que impuso, de una vez - así creo para $C R$ - o en más de una etapa, unas intervenciones restauradoras. Ese antecedente es $\eta$ : la ed. sinóptica de los textos me exime de dar aquí la lista de lecciones separativas y conjuntivas que demuestran el ascendiente común para $P$ y $C R$ y excluyen una relación directa. $P$ y $M N$ difieren sólo en ligeras váriantes gráficas y podrían ser el uno reimpresión del otro.

En cambio, señalo las que me parecen pruebas de un contacto por separado de $1 S 50 Z$ y de $1 S 50 B$ con $C R$, pese a la opinión de Rodríguez-Moñino sobre la derivación del segundo directamente del primero: La Silva de Romances de Barcelona, 1561, Salamanca, 1969, p. 125. Se trata de los vv. de $C R 18,23$, $26,38,54$ y 86 donde $1 S 50 Z$ presenta singulares mientras $1 S 50 B$ coincide con $C R$. Al recorrido inverso $-1 S 50 Z$ derivado de $1 S 50 B$ - se oponen los vv. 22 y 75. Creo que la historia de todos estos impresos es más complicada de lo que dejan suponer los cotejos por bloques de textos, ya que el itinerario que lleva a sendos poemas puede ser diferente del que ha seguido la mayoría de los textos, sobre todo cuando el mismo impresor avisa que ha retocado algunos romances: ibidem, p. 376 para 1 S50B. Es superfluo llamar la atención sobre influencias de la tradición oral, también a través de la memoria de recopiladores y tipógrafos, y que dan lugar a coincidencias notables, fuera y en contra de la coherencia simplicadora - que no irreal- de un stemma: cf. el aparato para el v. 75 de $C R$ donde $1 S 50 B$ concuerda con $G$ y $C a$, o sea con $\gamma$.

El stemma que he dibujado parte de la primacía de un tipo de texto del Romance como el que nos dan $\mathrm{G}$ y $\mathrm{Ca}$. Pero, dentro de la documentación actual, nada se opone a la hipótesis de un texto inicial ya con la contaminación en el exordio, un texto como el que atestiguan $P$ y $C R$, limitadamente a este punto. Una posible huella de tal configuración queda en los vv. 3-4 de $G$ y de $C a$, cuya conjunción remite a $\gamma$, versos que muy poco se explican en su texto: cf. supra, § III. 1. En tal caso, $\gamma$ sería el lugar de la caída del exordio "espurio" que llegaba de $\alpha$ y que no encuentra obstáculos en la ladera derecha del stemma. Repito una vez más que las que indico son estaciones simbólicas de trazados verosímiles.

Como consecuencia de cuanto antecede, y considerando los rasgos muy marcados de cada uno de los testimonios básicos del Romance - y de tres de ellos sobre todo-, doy a continuación una ed. sinóptica de $G, C a, P$ y $C R$, recogiendo debajo de este último las variantes de sus descendientes. Huelga avisar que los espacios en blanco dentro de un texto se deben a las exigencias de la disposición sinóptica y no señalan ninguna laguna, como la numeración de los versos delata claramente. Las modernizaciones gráficas son las usuales y mínimas. 
En Alcaudete esta el buen rey, en esse lugar honrrado.

En Jaén tuvo la fiesta en Martos el cavodeaño,

5 cuando le dieron querella de dos hombres hijos d'algo,

de don Pedro Carvajal y don Alonso su hermano porque rovaban las tierras

10 y porque corrían el campo.
En Jaén está el buen rey, esse buen rey don Fernando; en Jaén tuvo la pascua $y$ en Martos el cabo d'año,

5 e vase para Alcaudete esse castillo nombrado.

Los pies tiene en el estribo que no ha descavalgado, cuando le davan querella

10 d'aquesos dos hijos d'algo,

de don Pedro Carvajal e don Alonso su hermano que le robavan la tierra y le corrían el campo,

15 que le fuerçan las donzellas a tuerto e a $\sin$ guisado. 
$P$

Válame Nuestra Señora que dizen de la ribera donde el buen rey don Fernando tuvo la su cuarentena.

5 Dende el miércoles corvillo hasta el jueves de la cena el rey no afeitó su barba ni se lavó su cabeça; una silla era su cama,

10 un canto su cabecera; cuarenta pobres comían cada día a la su mesa, de lo que a los pobres sobra el rey hazia su cena;

15 con vara de oro en mano bien haze servir su mesa. Dízenle sus cavalleros dó havía de tener la fiesta. -A Jaén, 一dize- señores,

20 con mi señora la reina. -

En Jaén tuvo la pascua y en Martos el cabodaño. Pártese para Alcaudete, esse castillo nombrado.

25 El pie tiene en el estribo, aun no havía descavalgado, cuando le davan querella de dos hombres hijos d'algo y dávanle la querella

30 dos hombres como villanos:

-iJusticia, justicia!, el rey, pues que somos tus vassallos, de don Pedro Caravajal y don Rodrigo su hermano,

35 que nos corren nuestras tierras y nos roban nuestro campo, fnérçanos nuestras mugeres a tuerto y desaguisado
$C R$

Válasme Nuestra Señora cual dizen de la ribera donde el buen rey don Fernando tuvo la su cuarentena,

5 desd'el miércoles corvillo hasta el jueves de la cena qu'el rey no hizo la barba ni peinó la su cabeça; una silla era su cama,

10 un canto por cabecera; los cuarenta pobres comen cada día a la su mesa de lo que a los pobres sobra el rey haze la su cena;

15 con vara de oro en su mano bien haze servir la mesa.

Dízenle sus cavalleros: — ¿Dónde irás tener la fiesta? -A Jaén, -dize- señores,

20 con mi señora la reina.

Después que estuvo en Jaén y la fiesta ovo passado, pártese para Alcaudete esse castillo nombrado.

25 El pie tiene en el estrivo que aun no se avía apeado, cuando le davan querella de dos hombres hijos d'algo e la querella le davan

30 dos hombres como villanos: abarcas traen calçadas e aguijadas en las manos: - iJusticia, justicia!, rey, pues que somos tus vasallos,

35 de don Pedro Carabajal e de don Alonso su hermano, que nos corren nuestras tierras e nos robavan el campo e nos fuerçan las mugeres

40 a tuerto e desaguisado, 7.la]su $\quad 1 S 50 B, \quad 1 S 52 B . \quad 17$. sus]los $1 S 50 B, 1 S 52 B$. 18.d.yra a t.la f. CR68; que a do yra a t. la f. $1 S 50 Z$; d. yra a t. las fiestas $1 S 50 B, 1 S 52 B$. 22.e las fiestas an $\mathrm{p}$. $1 S 50 B, 1 S 52 B . \quad 23$. yuase $1 S 50 Z$. 26. se a.a.] hauia caualgado $1 S 50 Z$. 36.de]om. 1S50Z. 38. roban el ganado $1 S 50 Z$. 
Mándalos prender el rey

Mándalos prender el rey y buscar por su reinado: cualquiera que los hallare que le darán buen hallazgo.

15 Hallólos el Almirante allá en Medina del Campo: comprando estavan arneses, cuviertas a sus cavallos.

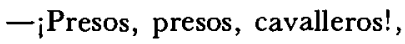

20 que del rey me era mandado. -Pláçenos - diçen-, señor, por cumplir el su mandado.-

Ya se parten los cavalleros, ya se parten los hijos d'algo,

25 con los grillos a los pies y con esposas a las manos. Jornada de quinçe días en ocho la avían andado. Hallado an al buen rey,

30 a esse rey don Fernando. -Manténgate Dios, señor. Dos prisioneros vos traigo: don Pedro de Carvajal y don Alonso su hermano.-

35 -Idos a comer, Almirante, $y$ ponedlos a rrecado.

e poner a buen recaudo. 
y cómennos la cevada,

40 no nos la quieren pagar; hazen otras desvergüenças que era vergüença contallo.-Yo haré d'ellos justicia.

Tornaos a vuestro ganado. -

45 Manda pregonar el rey y por todo su reinado que cualquier que los hallasse le darían buen hallazgo.

Hallólos el Almirante

50 allá en Medina del Campo, comprando muy ricas armas, jaezes para sus cavallos, para ir a ver el pregón que el buen rey avía dado.

55 - ¡Presos, presos, cavalleros, presos, presos, hijos d'algo!- No por vos, el Almirante, si de otro no es mandado.-Sed presos, los cavalleros,

60 que del rey traigo mandado. -Pues assí es, el Almirante, plázenos de muy buen grado.-

Por las sus jornadas ciertas a Jaén havían llegado.

65 - Manténgate Dios, el rey.-

—Mal vengades, hijos d'algo._- comíannos la cevada sin después querer pagallo; hazen otras desvergüenças que vergüença era contallo.

45 -Yo haré d'ello justicia. Tornaos a vuestro ganado. Manda a pregonar el rey e por todo su reinado de cualquier que los hallasse

50 le daría buen hallazgo. Hallólos el Almirante allá en Medina del Campo, comprando muy ricas armas jaezes para cavallos.

55 - $\mathrm{i}$ Presos, presos, cavalleros, presos, presos, hijos d'algo!- No por vos, el Almirante, si de otro no traéis mandado.- Estad presos, cavalleros,

60 que del rey traigo recaudo.-Plázenos, el Almirante, por complir el su mandado.-

Por las sus jornadas ciertas en Jaén avían entrado.

65 - Manténgate Dios, el rey.-

- Mal vengades, hijos d'algo. - 
Dende en terçero día la sentencia avía dado: que les cortasen los pies

40 y les cortasen las manos y les sacasen los ojos, los sus ojos entrambos, y mandólos despeñar de aquella peña de Martos

45 o de la sierra de Aillón porque cayesen de más alto.

- ¿Por qué lo mandáis, buen rey, sin haçeros desaguisado? Que nunca os vendimos villa

50 ni os dejamos en el campo: siempre os fuimos leales como leales vasallos. Mas, pues lo mandáis, señor, cúmplase vuestro mandado.

55 Mas enplaçámoste, rey, ante Dios el soverano que de oy en treinta días seas con nos al plaço; y tomamos por testigos

60 a san Pedro y a san Pablo

y nuestra procuradora a la Virgen sin peccado, tomamos por acusador a Luçifer el diablo.-
Mándales cortar los pies, mándales cortar las manos,

mandávalos despeñar de aquessa peña de Martos o de la sierra de Ailló porque caigan de más alto.

25 Allí fabló el menor d'ellos, que era más acostumbrado:

-Emplazámoste, el buen rey, para ante el Rey de lo alto que de oy en treinta días que tú ayas de ir al plazo.-

Oy cumples los veinte y nueve de mañana has d'ir al plazo. - 
Mandóles cortar los pies, mandóles cortar las manos

y mandólos despeñar

70 de aquella peña de Martos.

Allí habló el menor d'ellos, el menor y más osado: - ¿Por qué nos matas, el rey, siendo $\tan \mathrm{mal}$ informado?

75 Pues quexámonos de ti al Juez que es soberano, que dentro de treinta días con nosotros seas en plazo, y ponemos por testigos

80 a sanct Pedro y a sanct Pablo, ponemos por testimonio al apostol Sanctiago.-

E sin más poder dezir mueren estos hijos d'algo.
Mándales cortar los pies, mándales cortar las manos

e mándalos despeñar

70 de aquella peña de Martos.

Aí hablara el uno d'ellos, el menor e más osado: - ¿Por qué lo hazes, el rey? ¿Por qué hazes tal mandado?

75 Querellámonos, el rey, para ante el Soberano que dentro de treinta días váis con nosotros a plazo, e ponemos por testigos

80 a san Pedro e a san Pablo, ponemos por escrivano al apostol Santiago.-

El rey, no mirando en ello, hizo complir su mandado

85 por la falsa información que los villanos le han dado. Y muertos los Carvajales que lo avían emplazado, 
65 Dende veintiçinco días el rey estava muy malo, $y$ dende los veinte y siete ya estava confesado, y aun a los veinte y ocho

70 el Señor le avían dado, y dende los veinte y nueve la unçión le avían dado,

no eran cumplidos los treinta cuando el rey era finado.

\section{Roguemos todos a Dios} que él quiera perdonallo.
Ellos en aquesto estando, estas palabras hablando,

35 dio al rey una maletía, cuasi dolor de costado.

¡Oh qué mal doliente haze esse buen rey don Fernando!: los pies tiene cara oriente

40 y la candela en la mano; a sus fijos todos cuatro a su cabecera tiene: e los tres eran ligítimos, el otro era bastardo;

45 esse que bastardo era quedava mejor librado: arçobispo de Toledo y en las Españas primado.

- Si yo no muriera, fijo,

50 yo os llegara a Padre Santo; mas con la renta que os queda bien podréis, hijo, alcançallo.-

E acabada esta razón, el alma a Dios havía dado.

55 Así murió este buen rey por la sententia que avía dado. 
85 Antes de los treinta días malo está el rey don Fernando:

el cuerpo cara oriente y la candela en la mano.

Assi fallesció su alteza, 90 d'esta manera citado. antes de los treinta días 90 él se fallara muy malo;

y desque fueron cumplidos, en el postrer día del plazo,

fue muerto dentro en León, do la sentencia ovo dado.

90. fallaua $1 S 50 Z, 1 S 50 B, 1 S 52 B$.

Faltas mecánicas en los testimonios: CR:v. 3 Feruando 49 lo. CR68:v. 64 auia. $\quad$ 1S50Z:v.92 palazo. $1 S 52 B:$ v. 47 al 94 hono. Ca:v.20 los. G:v.37 Donde 63 acusados.

Grafias particulares: G:v.14 daram $62 \mathrm{sim}$. 